\title{
فعالية برناهج قائم على العلاج بالقبول والالتزام عبر الإنترنت في خفض أعراض التنهر الوظيفي لدى عينة هن أعضاء هيئة التدريس
}

\section{أ.د/ بشرى إسماعيل أحمد أرنوط}

\section{استاذ علم النفس الإرشادي \\ بكلية التربية جاهعة الملك خالد}

\section{وكلية الآداب جامعة الزقازيق}

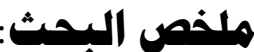

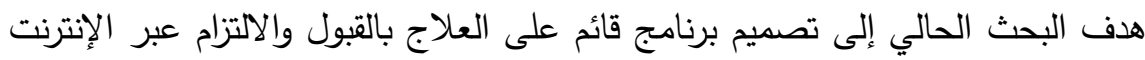

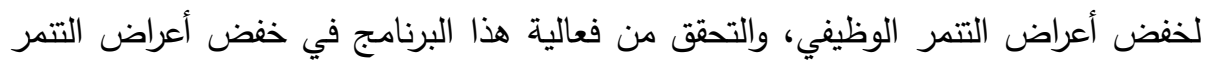

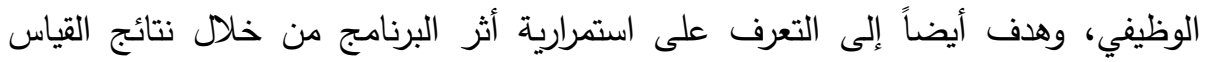

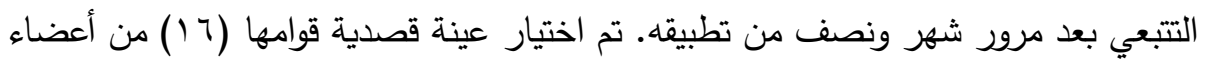

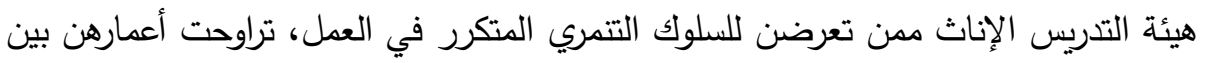

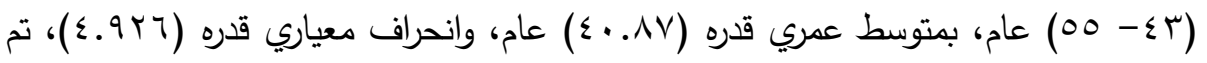

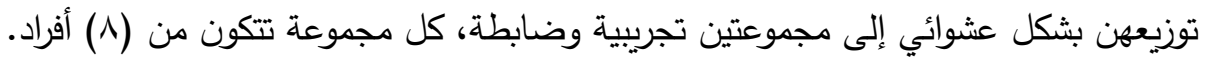

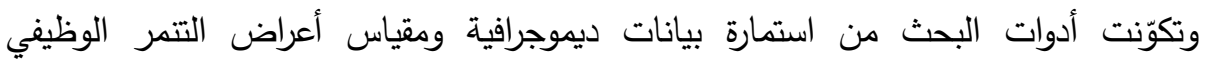

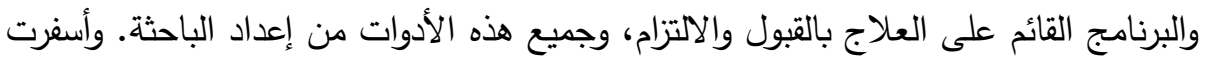

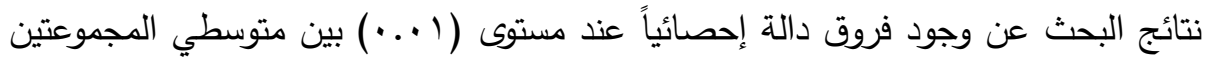
الضابطة والتجريبية في مقياس أعراض التتمر الوظيفي في التطبيق البعدي لصالح التهري أفراد

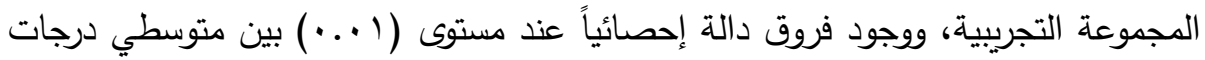

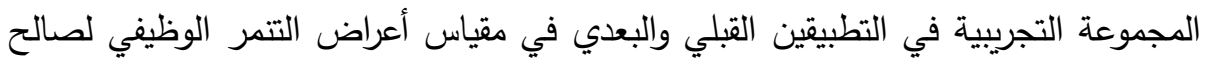

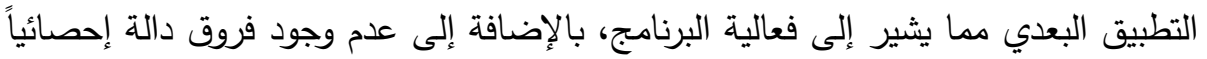

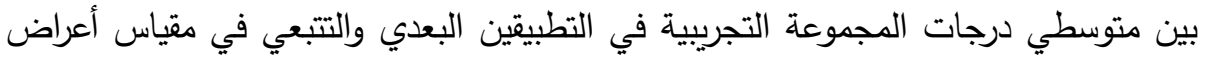

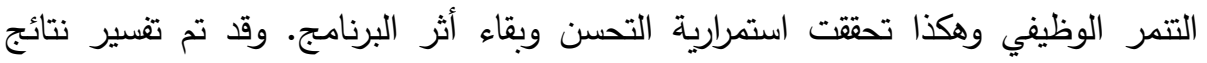

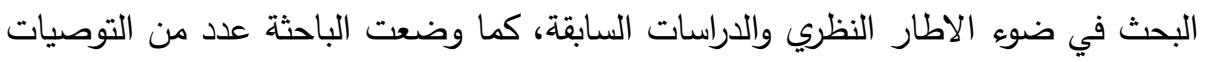

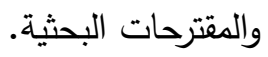




\section{فعالية برنامج قائم على العلاج بالقبول والإلترام عبر الانتزنت =}

الكلمات الهفتاحية: برنامج ، العلاج بالقبول والالتزام، العلاج النفسي عبر الانترنت، التتمر

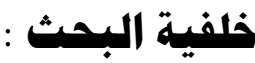

إن التطور التكنولوجي السريع في مجتمع اليوم، وما صاحبه من تغيرات اجتماعية

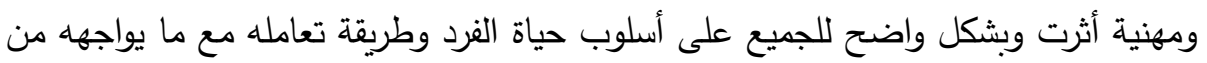

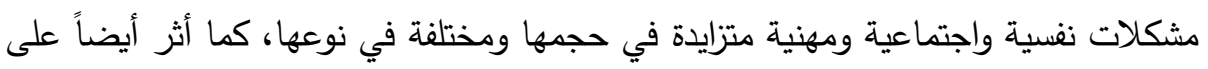

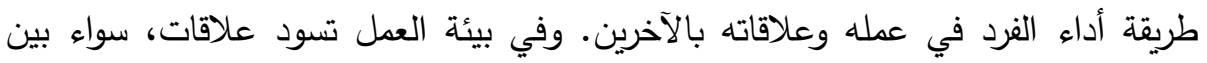

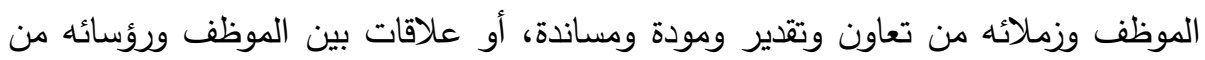
احترام متبادل وتقدير ودعم وتشجيع ومشاركته في عملية اتخاذ القرارات. ولذلكلك على القائد

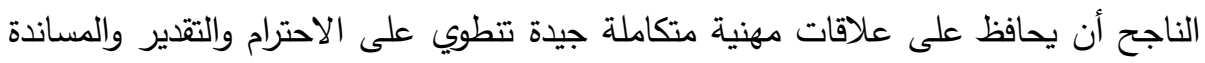

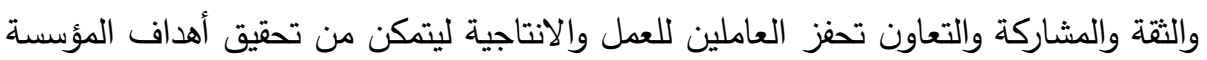

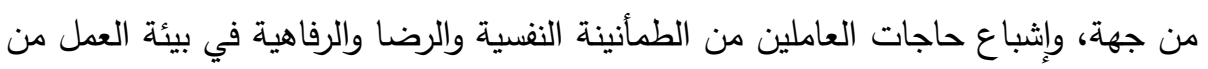

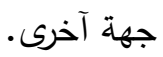

وفي اللحظة التي يبدأ فيها شخصان في التفاعل، ينشأ مناخ التواصل، فتارة يكون إيجابياً

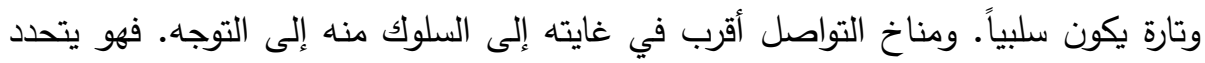

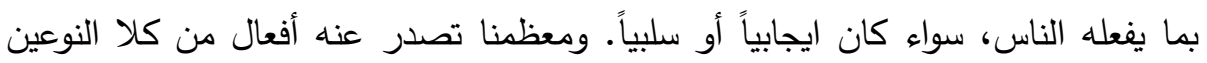

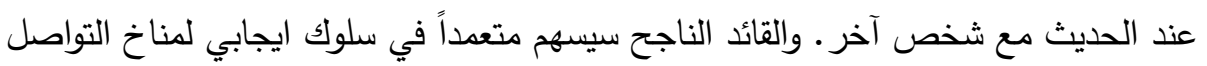

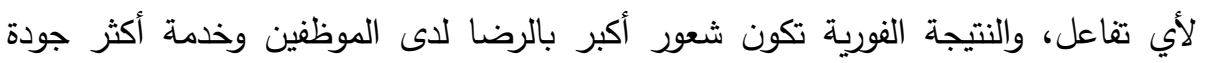

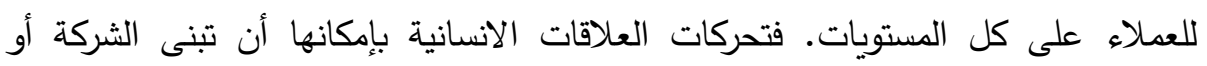
تهذمها. والرئيس الناجح سيعرف كيف يستخدم تلك التحركات في دعم أهداف المؤسسة وبناء الثقة بأنفسه والآخرين وخلق بيئة عمل قوية، فالقادة الفاعلون يتمتعون بمهارات تواصل التهل

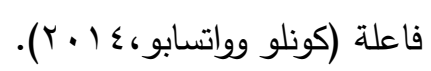

يعتبر التتمر في بيئة العمل أحد إفرازات التطور التكنولوجي والمعرفي الذي أثقل كاهل

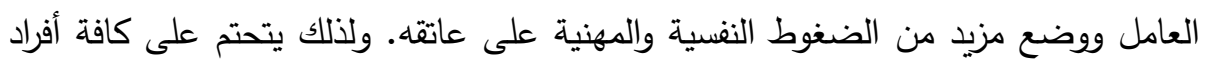
المجتمع ومؤسساته مواجهته والتخلص من آثاره السلبية على الفرد والمؤسسة والمجتمع. إن إن

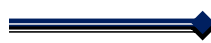




\section{أ.د. بشرى اسماعيل احمد أرنوط}

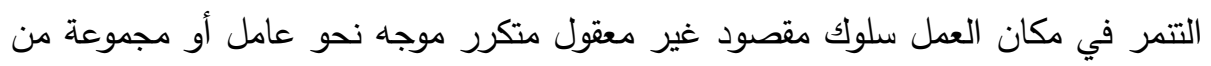

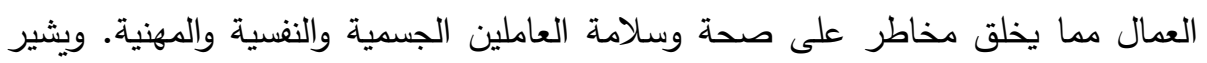
السلوك المتكرر إلى الطبيعة الدائمة للسلوك التتمري ويمكن أن يتضمن نطاقًا أوسع من العنائ

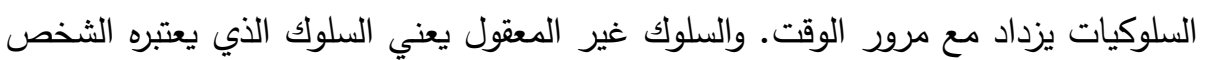

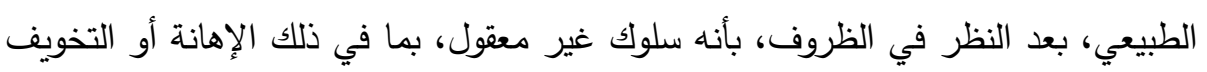

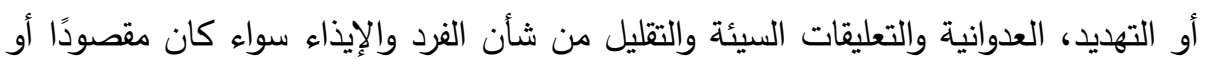

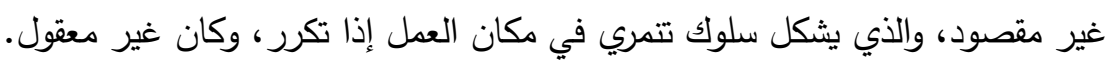

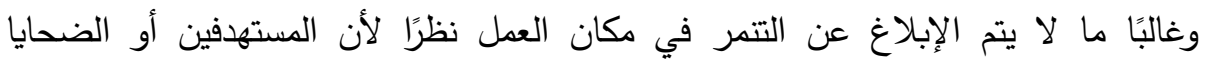

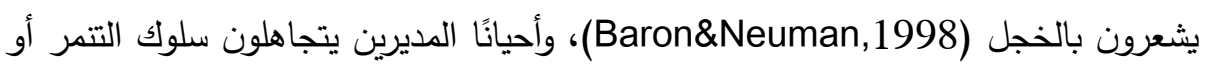

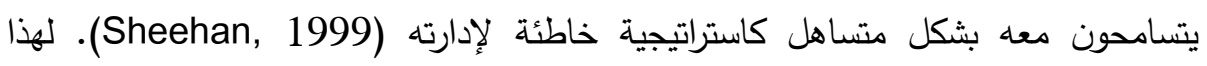

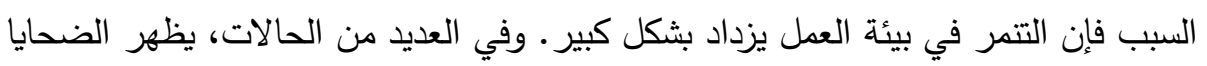

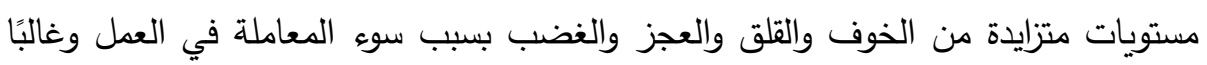
ما ينقلون هذه المشاعر السلبية إلى حياتهم الشخصية(Einarsen \&Mikkelsen,2003). فقد أشارت منظمة الصحة العالمية (WHO,2010) أن التتمر في بيئة العمل يمثل مشكلة صحية كبرى، تحتاج وقت وتضافر للجهود من المهتمين بتقديم الرعاية الصحية للعاملين،

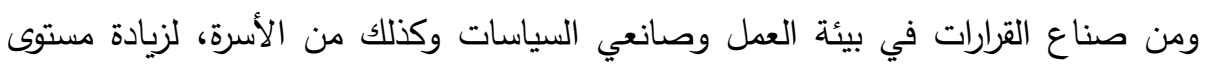

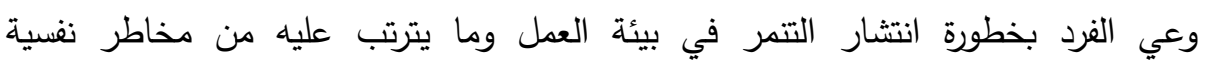

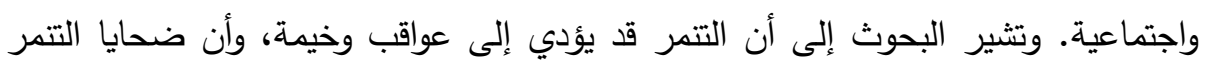
لديهم فرصة أكثر لتطوير اضطرابات جسدية وانفعالية(Vanderbilt\&Augustyn,2010). وغالبا ما ينطوي التتمر في مكان العمل على إساءة استخدام السلطة أو تكون القيادة سيئة

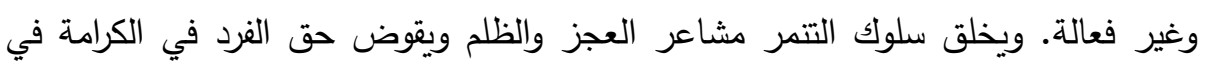
مكان العمل (Salin\& Hoel,2011).

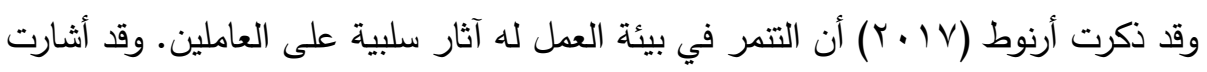

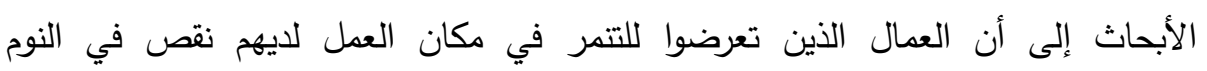

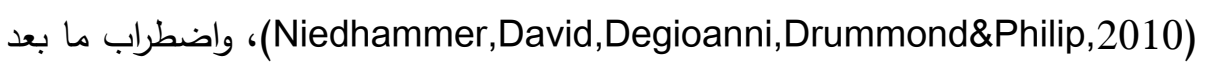

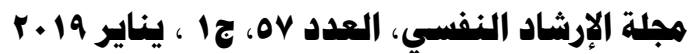




\section{فعالية برناهج قائم على العلاج بالقبول والإلتزام عبر الانتزنت =}

الصدمة (Matthiesen\&Einarsen,2004)، والاكتئاب(Quine,2001) و والمشاكل الجسدية(Zapf,Knorz\&Kulla,1996). إن التتمر في بيئة العمل قد لاقى اهتمام أقل بل يكاد ينعدم في البيئة العربية، رغم انتشاره

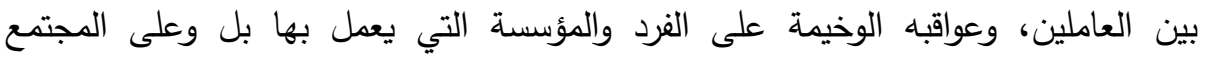

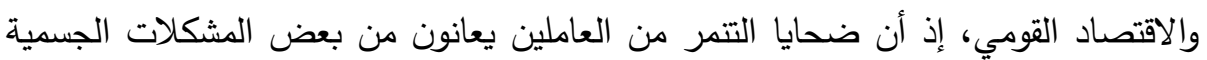

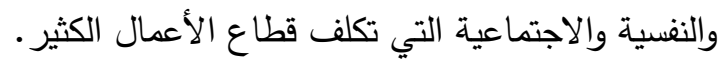
فالتتمر في مكان العمل يمكن أن يؤثر سلبًا على الصحة الجسمية والنفسية للفرد. ولهذا يعتبر

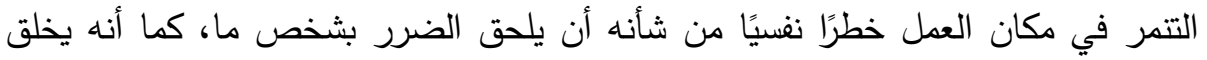

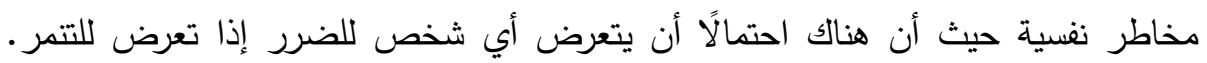
ولكن إذا وضعت تدابير رقابة فعالة لمعالجة وحل مشاكل العمل في وقت مبكر ، يمكن

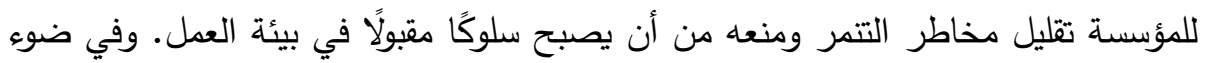
ما يشهده العالم من تطور تكنولوجي هائل في كافة مجالات الحياة ولاسيما العمل، فإن فئن

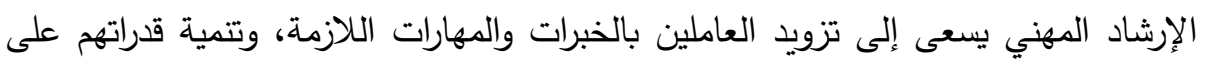

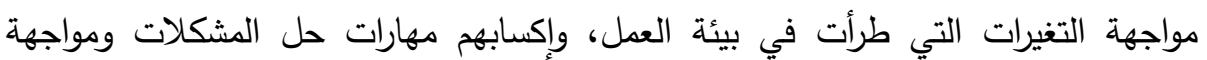
الصراعات في بيئة العمل. إن دراسة التتمر في بيئة العمل يسهم في التمكين النفسي للعاملين، بل وتمكين المؤسسات نفسها من حل مشكلات العمل بطرق فعالة وتحسين مستوى الصحة النفسية والمهنية للعاملين

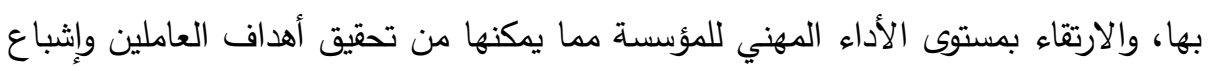

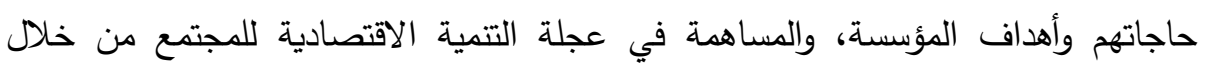
تخطيط البرامج الوقائية والنمائية والعلاجية لمشكلات العمل والانضباط المهني وعلى رأسها مشكلة التتمر •

وتعود أهمية دراسة موضوع التتمر في بيئة العمل إلى أمرين: أولهما: قيمة العمل في حياة

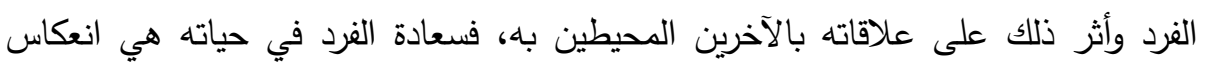
لسعادته في العمل والعكس صحيح. إذ أن توافقه المهني له تأثيرات على نفسية الفرد واتزانه وصحته الجسمية والنفسية في كافة جوانب الحياة الآخرى الأسرية والاجتماعية وغيرها.

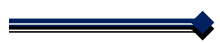




\section{أ.د. بشرى اسهاعيل احمد أرنوط}

الأمر الثاني: هو الآثار السلبية للتتمر في بيئة العمل سواء على مستوى الأفراد أو المؤسسات بل وعلى المجتمع بأكمله. فتعرض العامل للتنمر في بيئة عمله وشعوره بالتهديد التهري والتخويف يسبب له التوتر والقلق والاكتئاب والإجهاد مما يؤثر على انتاجيته ودافعيته

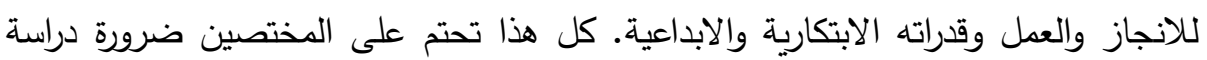
التتمر في بيئة العمل والوسائل والطرق والبرامج الإرشادية والعلاجية الممكنة للحد من آثاره

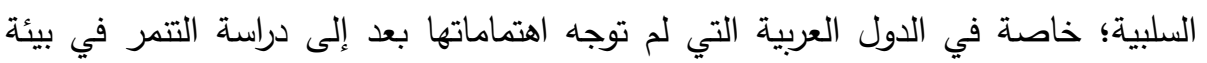
العمل مثلما اهتمت به الدول الأجنبية، حيث أجريت العديد من البحوث والدراسات، وأنشأت

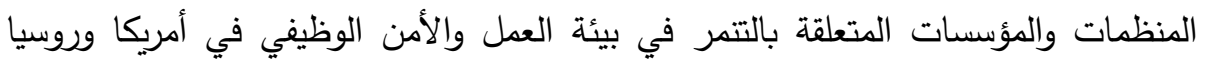
وغيرها من الدول الأجنبية. وهنا تتجلى أهمية الإرشاد والعلاج النفسي في بيئة العمل في نمو الثخص وتونة وافئه وصحته النفسية، فالمهنة لها علاقة وثيقة بالذات والثخصية. والمهنة ولهية هي العمل الذي سيقضي فيه فيه

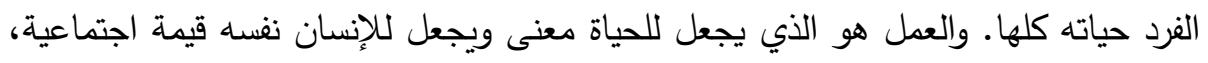

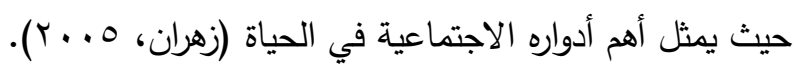

والتتمر في مكان العمل هو الموضوع الذي يؤثر على العديد من الناس في العديد من المهن

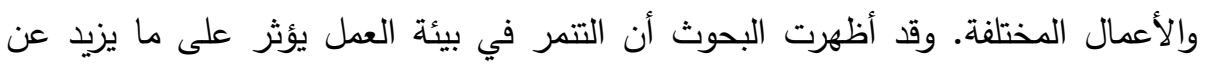
نصف جميع العمال خلال تاريخ عملهم، وعندما يصبح التتمر في العمل نمطا راسخا، لاشك لئك أن معالجته أو التخفيف منه بشكل فعال يكون صعب (Kyla,2016).

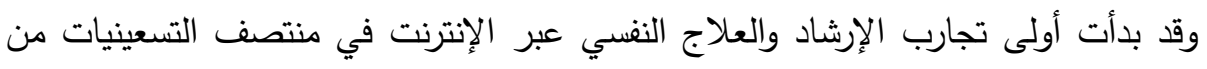

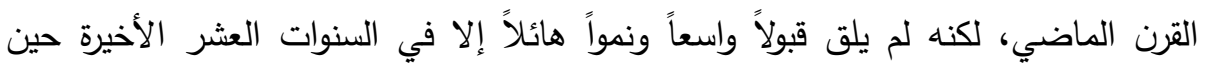

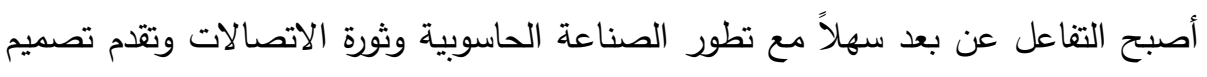

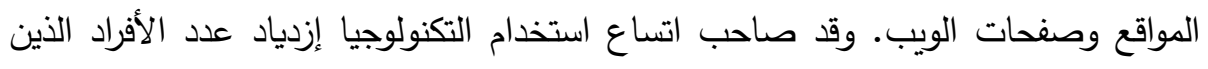

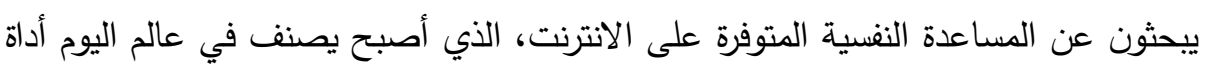

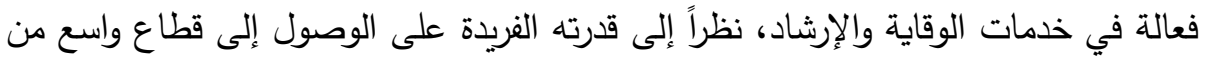

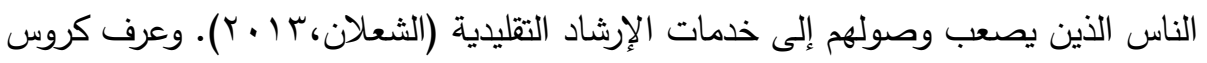
وآخرون (Kraus etal, 2010) العلاج النفسي عبر الإنترنت بأنه كافة الاستشارات والخدمات الاكلينيكية التي تقدم من خلال التطبيقات المختلفة للإنترنت مثل الرسائل، التحدث

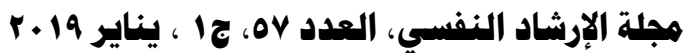




\section{فعالية برناهج قائم على العلاج بالقبول والإلتزام عبر الانتزنت =}

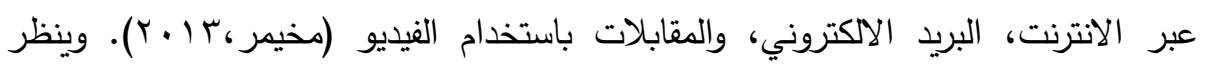

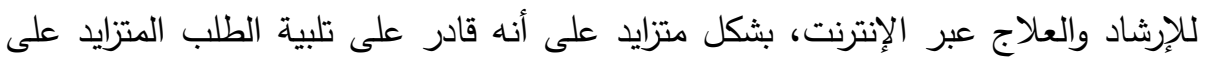

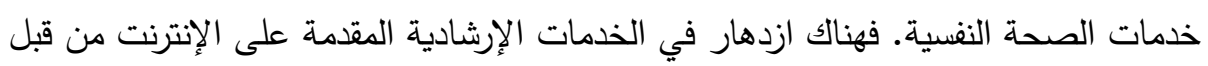

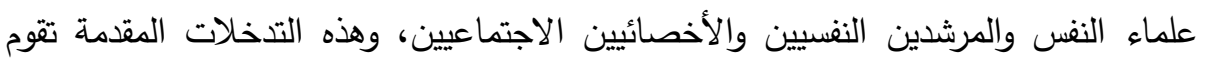

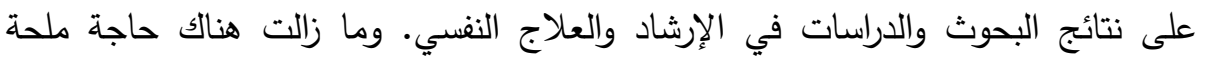
لإجراء المزيد من البحوث حول الكشف عن فعالية الإنترنت في تقديم الخدمات الإرشادية للمسترشدين (Dowling\&Rickwood,2013). وازدهرت حركة الإرشاد والعلاج النفسي عبر الإنترنت في السنوات الأخيرة، نظراً لما يتميز به

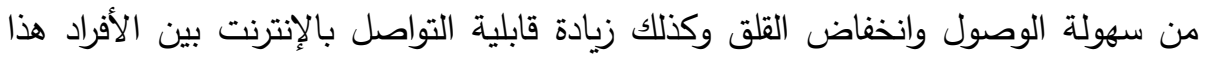

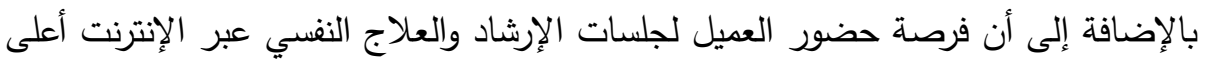

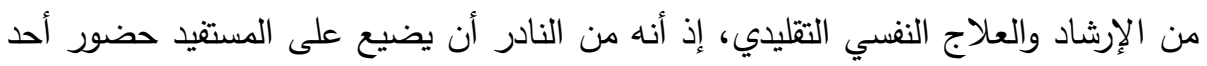

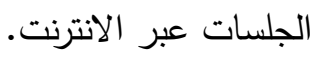
وذكر جريفث (Griffith,2001) عدة فوائد للإرشاد والعلاج النفسي عبر الإنترنت منها انخفاض المرغوبية الاجتماعية لاى العملاء مما يجعل نتائج الإرشاد والعلاج عن بعد أكثر مصداقية عن الإرشاد التقليدي، كذلك يتميز بانخفاض شعور العميل بالوصمة الاجتماعية

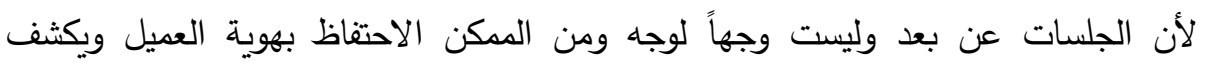

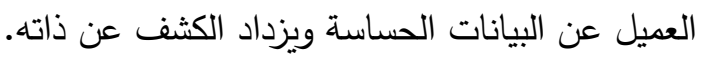
ويعد العلاج بالقبول والالتزام مناسباً للاستخدام مع الأفراد الذين يتم تشخصيهح على أنهر يعانون من ظروف حياتية مرضية أو قاسية ومن المشاكل الحياتية (على سبيل المثال مشكلات العلاقات، والمشكلات الوظيفية أو المهنية). ومن التطبيقات الهامة للعلاج بالقبول

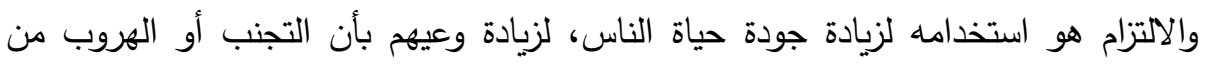
المواقف هي التي تجعلهم لا يعيشون الحياة التي يرغبون فيها، مما يجعلهم يلتزمون بتغيير سلوكياتهم (Orsillo\&Batten,2005). وقد أجريت العديد من البحوث والدراسات حول فعالية العلاج بالقبول والالتزام مع العديد من المشكلات النفسية وعلى عينات عمرية مختلفة، واتضح من نتائجها ما يلي: 


\section{أ.د. بشرى اسماعيل احمد أرنوط}

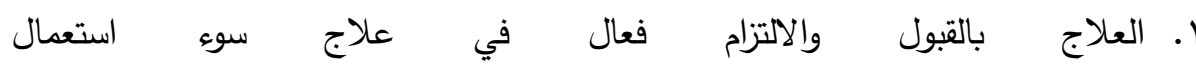
العقاقير (Hayes,StrosahI\&Wilson,1999; Marlatt,1994).

r. العلاج بالقبول والالتزام فعال في علاج الأعراض الذهانية (Bach\&Hayes,2002).

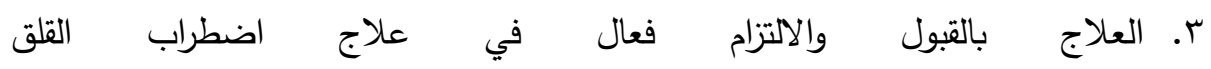
المعمم)(Roemer\&Orsillo,2002).

ع. كان العلاج بالقبول والالتزام فعال في تحسين الرفاهية الاجتماعية لدى الطلبة ذوي صعوبات التعلم(Narimani,Pourbdor\&Bashirpour,2004).

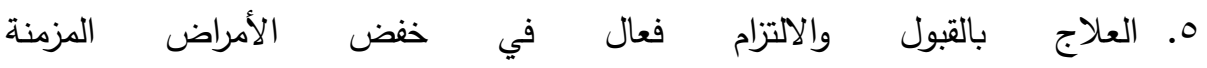
.(McCracken,Vowles\&Ecleston,2007)

7. استخدم العلاج بالقبول والالتزام بفعالية في خفض أعراض القلق والاكتئاب لدى الثباب والمسنين(Karlin,Walser,Yesavage,Zhang,Trockel\&Taylor, 2013). V. استخدم العلاج بالقبول والالتزام بفاعلية في خفض ضغوط العمل والاحتراق النفسي المهني(Hoseinaei,Ahadi,Fati,Heidari\&Mazaheri,2013).

^. استخدم العلاج بالقبول والالتزام بفعالية في علاج مشكلات العلاقات الشخصية وزيادة

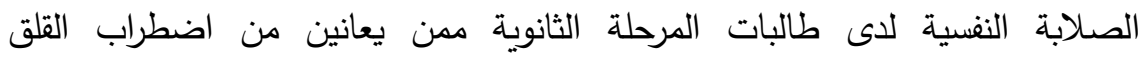
الاجتماعي( Azadeh,Zahrani\&Besharat,2016).

9. كذلك كان العلاج بالقبول والالتزام فعال في خفض الاضطرابات النفسية ( .(etal, 2017

• ا. العلاج بالقبول والالتزام فعال في زيادة التفاؤل والمرونة لدى المراهقين ذوي اضطراب الاكتئاب الاساسي (Towsyfyan\&Sabet,2017).

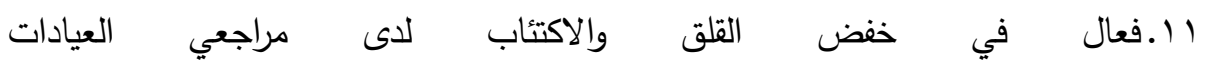
النفية)(Heyedari,Masafi,Jafari,Saadat\&Shahyad,2018).

ونظراً لميل ضحايا التتمر إلى تجنب المواقف التي تجمعهم مع المتتمرين، وعدم الرغبة في

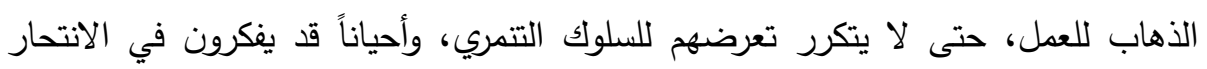
الذي قد يخلصهم من التحرش والعنف والتتمر الموجه لهم، فإن العلاج بالقبول والالتزام سيكون فعال في علاج الآثار السلبية للتمر (Orsilio\&Batten,2005). 


\section{فعالية برناهج قائم على العلاج بالقبـول والإلترام عبر الانترنت}

وفي ضوء ما توصلت إليه نتائج دراسة أرنوط (YlV) من وجود علاقة ارتباطية دالة

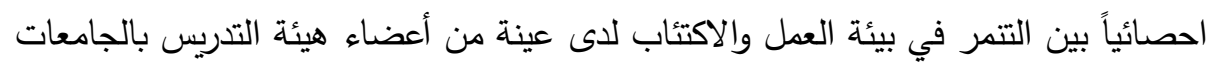
المصرية، وكذلك وجود مستوى مرتفع من تعرض أفراد عينة البحث للسلوكيات السلبية

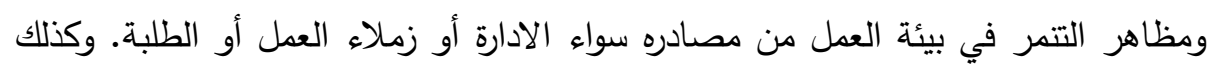

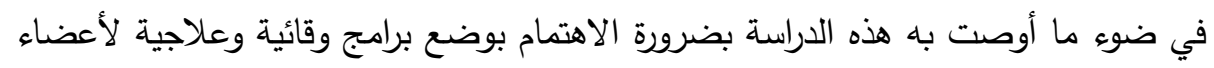
هيئة التدريس لخفض مستوى التتمر في بيئة العمل والتقليل من آثاره السلبية وذلك تحقيقاً لكبادئ ومعايير الجودة في مؤسسات التعليم العالي. فإن البحث الحالي يعد محاولة للكثف عن فعالية العلاج بالقبول والالتزام عبر الإنترنت في خفض آثار وأعراض التتمر في بيئة العمل. وبناء علي ما سبق يمكن طرح السؤال الرئيس التالي : ما فعالية العلاج بالقبول والالتزام عبر الإنترنت في خفض أعراض التتمر الوظيفي لاى أفراد عينة البحث؟ معانه وينبثق عن هذا السؤال العام عدة أسئلة فرعية، هي :

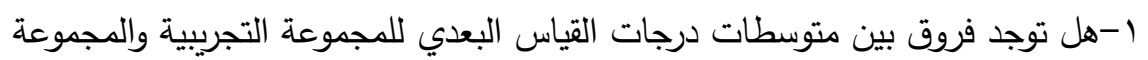
الضابطة على مقياس أعراض التتمر الوظيفي بعد تطبيق البرنامج عبر الانترنت؟ تونج r-هل توجد فروق ين متوسطات درجات القياس التبلي والبعدي للمجموعة التجريبية

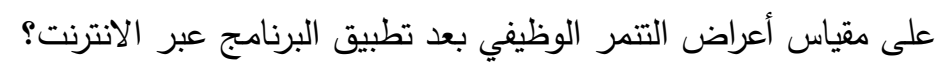

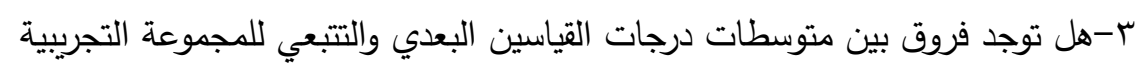

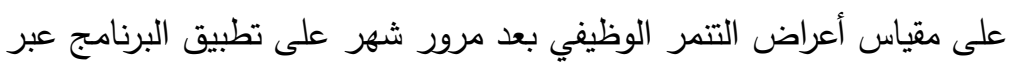
الانترنت؟

$$
\text { هدف البحث الحالي إلي: }
$$

1-تصميم برنامج قائم على فنيات العلاج بالقبول والالتزام في خفض أعراض التتمر الوظيفي لدى عينة من أعضاء هيئة التدريس. 


\section{أ.د. بشرى اسماعيل احهد أرنوط}

r- التحقق من فعالية البرنامج القائم على العلاج بالقبول والالتزام في خفض أعراض التص التتمر الوظيفي لاى عينة من أعضاء هيئة التدريس. r-تعرّف مدى استمرارية أثر البرنامج القائم على القبول والالتزام بعد الانتهاء من لنعبن تطبيقه عبر الانترنت.

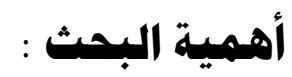

أولاً : الأهمية النظرية : النوان

1-يعد هذا البحث من باكورة البحوث والدراسات التي تهدف إلي إعداد برنامج قائم على : العي العلاج بالقبول والالتزام لضحايا التتمر الوظيفي في حدود علم الباحثة، وتعتبر هذه

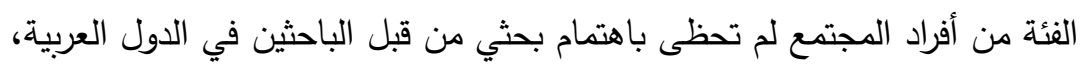

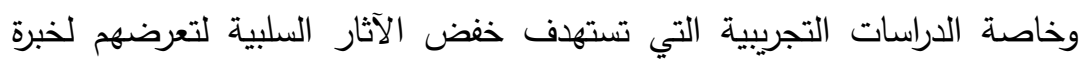
التنمر - التم

ץ-كما تتضح أهمية البحث في أنه دراسة تجريبية على ضحايا التتمر الوظيفي، ومن ثم توجيه أنظار المرشدين والمعالجين النفسيين في المؤسسات إلي تفعيل برائه علاجية لضحايا التتمر في بيئة العمل. r-تتبع أهمية البحث الحالي من موضوعاه وهو فعالية العلاج النفسي عبر الإنترنت لضحايا التنمر في بيئة العمل من خلال تطبيق فنيات العلاج بالقبول والالتزام. ع-ندرة الدراسات التي تتاولت بالبحث والدراسة متغير التتمر الوظيفي، مما يسهم في في فئي فتح أفاق بحثية مستقبلية في هذا الموضوع سواء كانت وصفية أو تجريبية. ه-تقديم مقياس للبيئة العربية لـ(أعراض التنمر الوظيفي) يسهح في إثراء المكتبة العربية

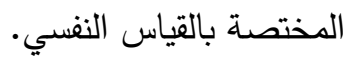
ثانياً : الاهمية التطبيقية : 1-في ضوء نتائج البحث الحالي يمكن تقديم عدد من التوصيات يمكن الاستفادة منها

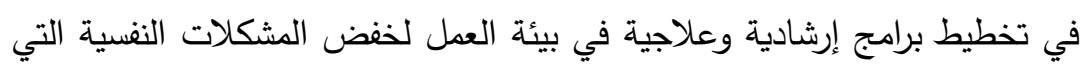

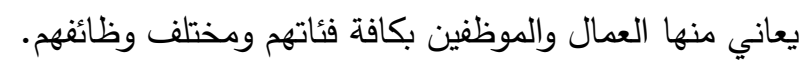




\section{فعالية برناهج قائم على العلاج بالقبول والإلتزام عبر الانترنت}

ץ-قد تفيد نتائج البحث الحالي في توجيه انتباه المسؤولين في بيئة العمل لأهمية الخدمات النفسية الإرشادية والعلاجية في ضوء برامج مساعدة العاملين وفاعليتها

في خفض ما يعانون منه من مشاكل نفسية ومهنية.

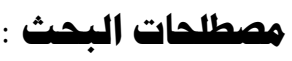

العلاج النفسي عبر الانترنت:

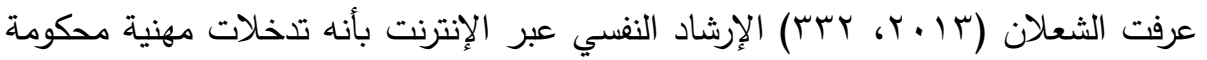

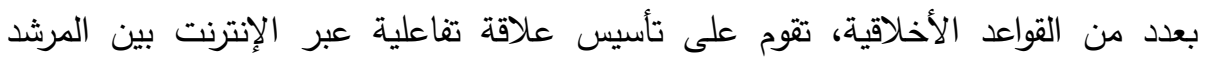
والمسترشد، تتضمن دمج مجموعة من الأساليب الإرشادية السلوكية والمعرفية والانسانية. كما عرف سيندال (Sindahl,2011,11) العلاج النفسي عبر الدردشة على أنه المساعداديه التي تقدم المعلومات والخدمات العلاجية والدعم للعميل ليتمكن من مواجهة المشكلات النفسية والاجتماعية باستخدام نظام تكنولوجيا الدردشة. حيث يتفاعل المعالج والعميل معاً في وقت واجت وله واحد من خلال استخدام أجهزة الكمبيوتر ووسائل الدردشة على شبكة الإنترنت.

$$
\text { برنامج قائم على العلاج بالقبول والالتزام : }
$$

A program based on Acceptance and Commitment

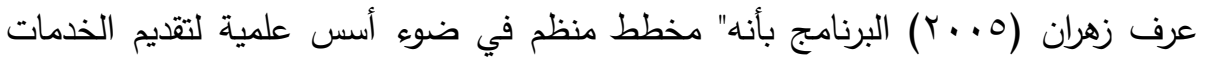

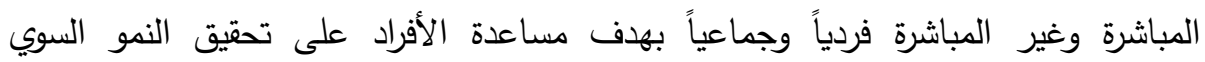

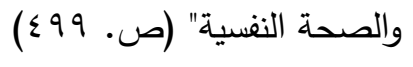

أما العلاج بالقبول والالتزام : Acceptance and Commitment Therapy

عرف ويلسون وموريل(Wilson\&Murrell,2003,49) العلاج بالقبول والالتزام بأنه ذلك الاسلوب الذي فيه يمكن للأشخاص أن يتعلموا إزالة الخبرات الداخلية السلبية من الأفكار

والذكريات والمشاعر والإحساسات الجسمية، وذلك باستبدالها بخبرات أخرى إيجابية.

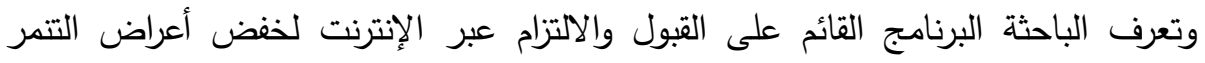
الوظيفي إجرائياً بأنه " مجموعة من الإجراءات والفنيات والأنشطة المتنوعة والخدمات المباشرة وغير المباشرة المعرفية المخطط لها، والتي تتناسب مع طبيعة وخصائص عينة البحث والتي تهدف إلى خفض أعراض سلوك التتمر الجسمية والنفسية والمهنية، والتي تقدم لأفراد

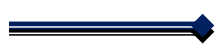




\section{أ.د. بشرى اسهاعيل احمد أرنوط}

المجموعة التجريبية في جلسات علاجية فردية عبر الإنترنت من خلال برنامج Skype،

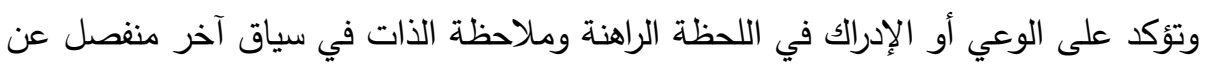

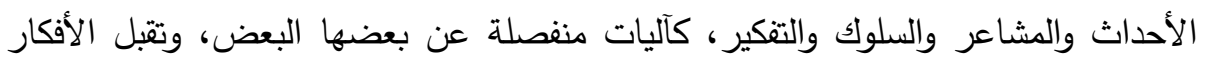

والمشاعر السلبية. أعراض التنمر الوظيفي :

عرفت فيزنزكييت(Visinskaite,2015,7) التتمر الوظيفي بأنه" سلوكيات غير مرغوب فيها

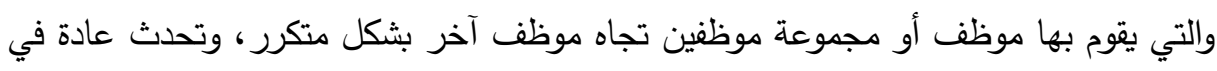

مكان العمل، ولها تأثير خطير على الفرد والمؤسسة التي يعمل بها".

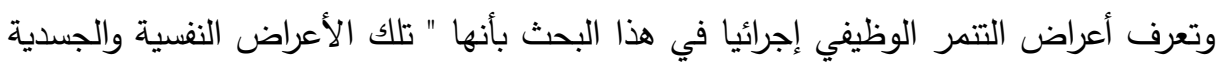

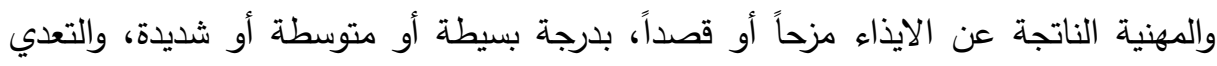
والقيام بعمل مؤذي بصورة متكررة، يقوم به فرد أو مجموعة أفراد في العمل إزاء زميلهم، نتيجة التهاء استقوائهم على ضعفه ولإيقاع الضرر به بشكل علني أو سري وبهدف النيل من ثقته وتتديره

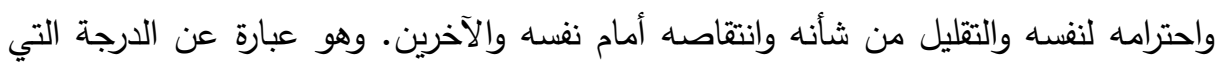
يحصل عليها الفرد على المقياس الذي أعدته الباحثة".

\section{فروض البحث :}

بناء على الإطار النظري لموضوع البحث الحالي وكذلك ما توصلت إليه البحوث والدراسات

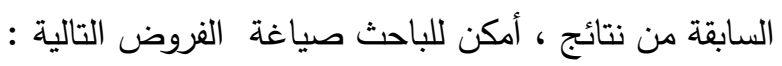
ا-توجد فروق ذات دلالة إحصائية بين متوسطي درجات المجموعتين الضابطة والتجريبية في مقياس أعراض التتمر الوظيفي بعد تطبيق البرنامج عبر الانترنت.

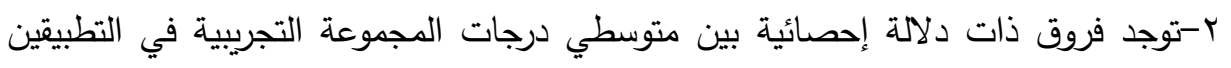

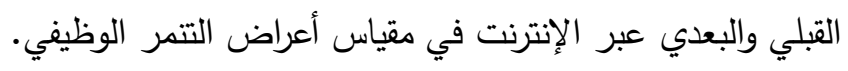
r-لا توجد فروق ذات دلالة إحصائية بين متوسطي درجات المجموعة التجريبية في التطبيقين البعدي والتتبعي عبر الإنترنت في أعراض التتمر الوظيفي. 
منهج البحث:

استخدمت الباحثة المنهج شبه التجريبي، والتصميم المستخدم هو التصميم القائم على

تقسيم العينة إلى مجموعتين تجريبية وضابطة، متكافئتين من حيث العمر، والجنس، والدرجة

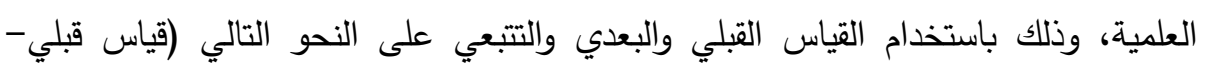
البرنامج - قياس بعدي - قياس تتبعي)، وتحددت متغيرات البحث على النحو التالي: المتغير ولئي

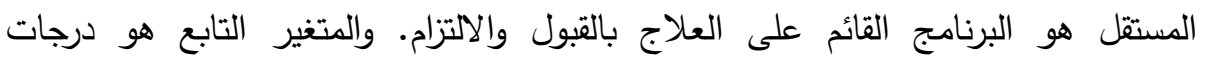
المجموعة التجريبية على مقياس أعراض التتمر الوظيفي. مجتمع البحث: تكون مجتمع البحث الحالي من جميع أعضاء هيئة التدريس بالجامعات المصرية.

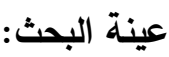

طبق مقياس أعراض التتمر الوظيفي علي عينة عشوائية ممثلة لمجتمع الأصل، إذ تكونت

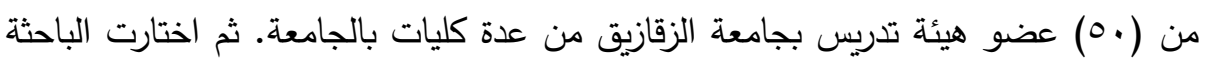

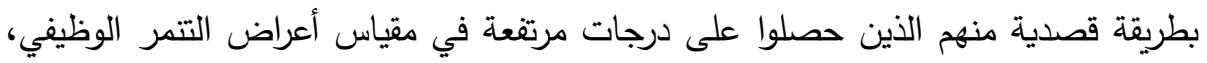

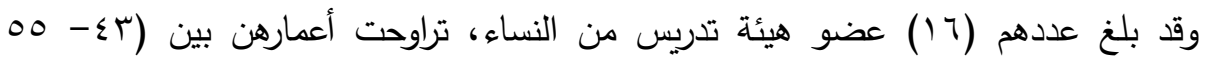

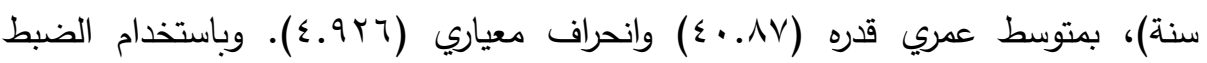
الانتقائي اختارت الباحثة هذه العينة وفقاً لخصائص معينة منها الجنس حيث كان كان جميع أفراد العينة من العنصر النسائي، كذلك الدرجة العلمية كان الجميع بدرجة الدكتوراه (مدرس ولفئه جامعي)، وعدد سنوات خبرتهم في هذه الدرجة العلمية بلغت م سنوات.

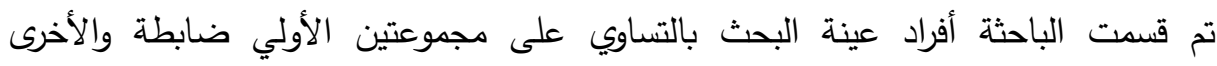

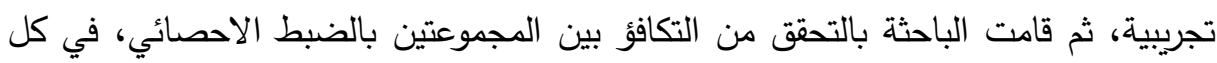
من متغير العمر والمتغير التابع (أعراض التتمر الوظيفي) قبل التطبيق؛ وذلك باستخدام اختبار (ت) لمجموعتين مستقلتين، والنتائج موضحة في الجدول التالي: 


\section{أ.د. بشرى اسهاعيل احمد أرنوط}

جدول (1)

اختبار (ت) لدراسة دلالة الفروق بين متوسطي درجات المجموعتين: الضابطة والتجريبية في العمر وأعراض

\begin{tabular}{|c|c|c|c|c|c|c|}
\hline \multicolumn{7}{|c|}{ التتمر الوظيفي قبل التطبيق } \\
\hline 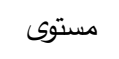 & قيمة (ت) & الانحراف & المتوسط & ن & المجموعة & 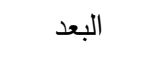 \\
\hline الدلالة الد & ودلالتها & المعياري & & & & \\
\hline \multirow[t]{2}{*}{ غير دالة } & \multirow[t]{2}{*}{. .095} & T.VTr & rq.7r & $\wedge$ & الضابطة & \multirow{2}{*}{ العمر | - ل العم } \\
\hline & & E.7rq & rı.o. & $\wedge$ & التجريبية & \\
\hline \multirow[t]{2}{*}{ غير دالة } & \multirow[t]{2}{*}{$1.1 \leqslant 1$} & V.乏AT & אוד.ד & $\wedge$ & الضابطة & \multirow{2}{*}{ أعراض التتمر } \\
\hline & & $\Lambda .7 \leqslant \Lambda$ & $9 . . \vee 0$ & $\wedge$ & التجريبية & \\
\hline
\end{tabular}

يتضح من نتائج الجدول السابق(1) عدم وجود فروق دالة إحصائياً بين متوسطي الجئي المجموعتين الضابطة والتجريبية في كل من العمر وأعراض التتمر الوظيفي قبل التطبيق،

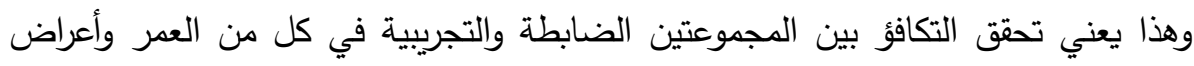
التتمر الوظيفي قبل التطبيق؛ وبذلك تحقق المتطلب السابق بتكافؤ المجموعتين: الضابطة والتجريبية قبل تطبيق البرنامج.

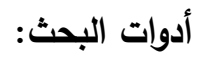

1- استمارة البيانات الديموجرافية: استمارة المستوى الاجتماعي والاقتصادي: قامت الباحثة بإعداد استمارة لجمع البيانات الديموجرافية فيما يتعلق بالجنس، والعمر ، والدرجة

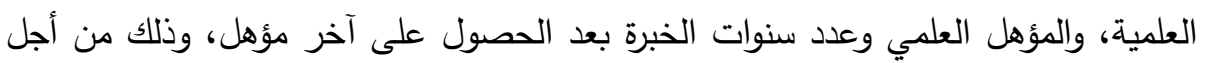
التأكد من تكافؤ المجموعتين التجريبية والضابطة، كمتطلب قبل تطبيق البرنامج على أفراد المجموعة التجريبية.

Career bullying Symptoms ب بمقياس أعراض التنمر الوظيفي (إعداد الباحثة) Scale

قامت الباحثة بإعداد مقياس أعراض التتمر الوظيفي وذلك لعدم وجود مقياس في البيئة

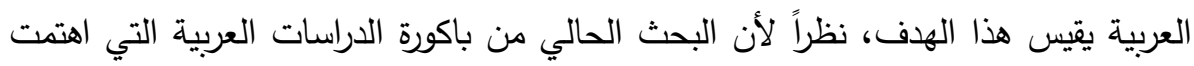

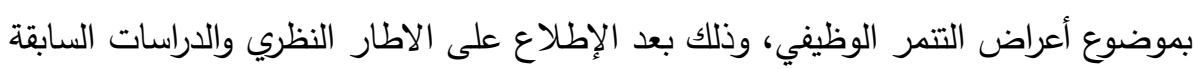

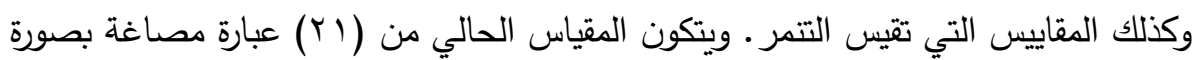
التقرير الذاتي وكلها بصيغة إيجابية في اتجاه المتغير المقاس، يتم الإجابة عنها بأختيار أحد

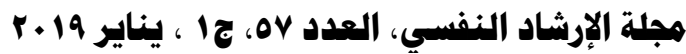




\section{نعالية برناهج قائم على العلاج بالقبول والإلتزام عبر الانتزنت =}

البدائل (أوافق بثدة، أوافق، محايد، لا أوافق، لا أوافق بثدة). وزعت عدد عبارات الكقياس

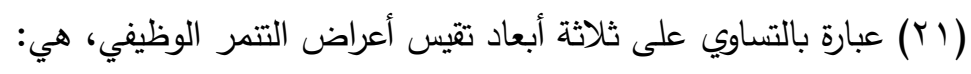

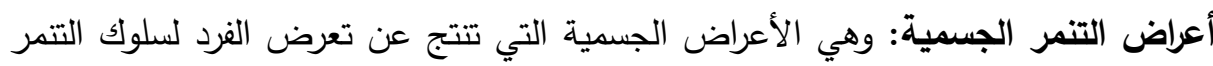

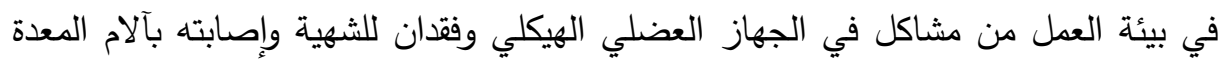

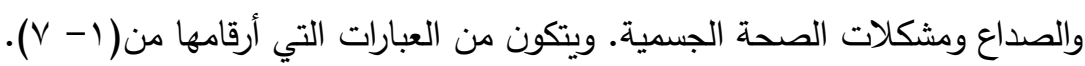

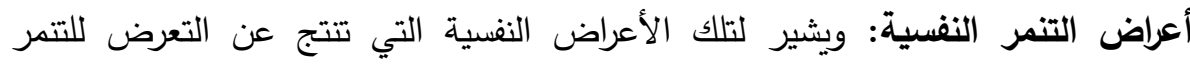

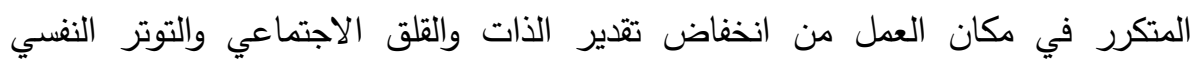

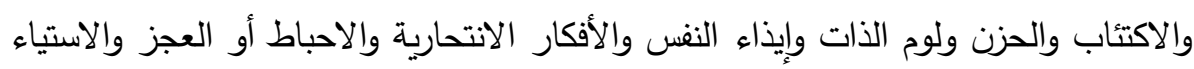

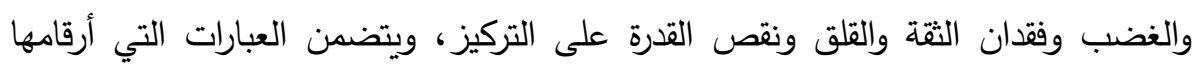

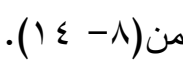
أعراض التنمر المهنية: مثل الانسحاب عن العمل والغياب المرضي وزيادة الغياب

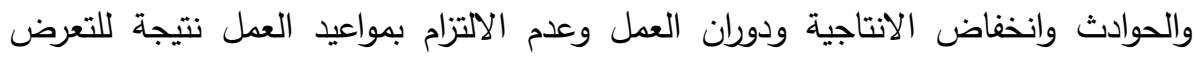

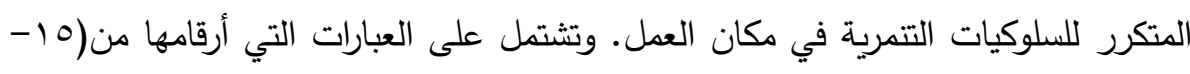

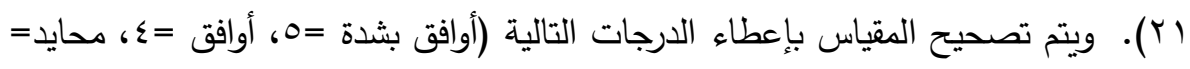

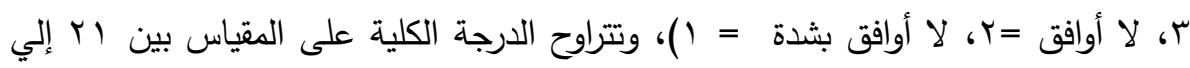

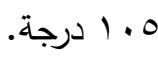
الخصائص السيكومترية للمقياس:

1- صدق المحكمين: تم عرض المقياس في صورته الأولية علي عدد من المحكمين

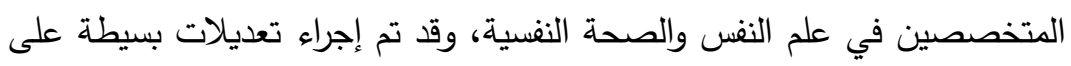

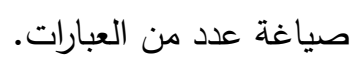

r- كذلك تم التحقق من الاتساق الداخلي بحساب معاملات الارتباط بين كل عبارة والدرجة الكلية للمقياس، وكذلك بين درجة كل عبارة وبين البعد الذي تنتمي إليه،

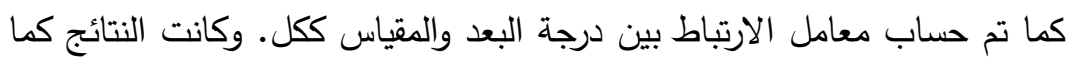

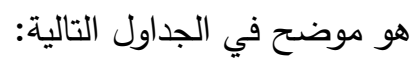




\section{أ.د. بشرى اسماعيل احمد أرنوط}

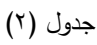

معاملات الارتباط بين عبارات مقياس أعراض التتمر الوظيفي والدرجة الكلية للمقياس

\begin{tabular}{|c|c|c|c|}
\hline معامل الارتباط & العبارة & معامل الارتباط & العبارة \\
\hline ***. & 11 & $* * .0 \leq \leqslant$ & 1 \\
\hline$* * .0 \leqslant r$ & ir & ***.VI. & r \\
\hline$* * .01 T$ & ir & $* * .700$ & r \\
\hline$* * . . \vee \leqslant \Lambda$ & $1 \leqslant$ & $* * . T V T$ & $\varepsilon$ \\
\hline$* * . .09 \varepsilon$ & 10 & $* * * .7 .1$ & 0 \\
\hline$* * . \vee \backslash \Lambda$ & 17 & $* * .0 Y \varepsilon$ & 7 \\
\hline$* * 010$ & iv & **. & v \\
\hline **. . Ory & 11 & **. . V r o & $\wedge$ \\
\hline$* * . .0 \leq 0$ & 19 & $* * \cdot V 71$ & 9 \\
\hline$* * \ldots \_\wedge$. & $r$. & $* * .79 r$ & 1. \\
\hline & & $* * . . \leqslant Y V$ & r) \\
\hline
\end{tabular}

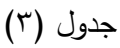

معاملات الارتباط بين عبارات مقياس أعراض التتمر الوظيفي والأبعاد

\begin{tabular}{|c|c|c|c|c|c|}
\hline معامل الارتباط & العبارة & الأبعاد & معامل & العبارة & الأبعاد \\
\hline **..Tr & Ir & & $* * . . \leq \leqslant 0$ & 1 & البعد الأول \\
\hline$* * . . \vee r$ & Ir & & $* * \cdot . V \cdot r$ & r & \\
\hline$* * . . \vee v$. & $1 \varepsilon$ & & $* * . . \vee V \leq$ & $r$ & \\
\hline$* * .71 \%$ & 10 & الثالث & $* * . \wedge r q$ & $\varepsilon$ & \\
\hline$* * . . \vee 91$ & 17 & & $* * . \wedge 7 \%$ & - & \\
\hline$* * .77 V$ & iv & & $* * .79 \%$ & 7 & \\
\hline$* * .799$ & 11 & & $* * \cdot v \cdot 1$ & v & \\
\hline$* * . .7 \leq r$ & 19 & & $* * . . V H$. & $\wedge$ & البعد الثاني \\
\hline$* * .74 r$ & $r$. & & $* *, V \leq q$ & 9 & \\
\hline$* * . . \leq r r$ & Y & & $* * . . \wedge \leq 7$ & 1. & \\
\hline & & & $* * . V I r$ & 11 & \\
\hline
\end{tabular}

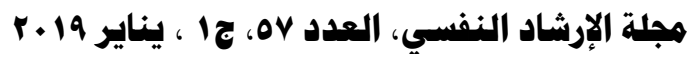

(10) 
جدول (乏)

\begin{tabular}{|c|c|}
\hline معامل الارتباط & الأبعاد \\
\hline$* *$. . & الأعراض الجسمية للتتمر \\
\hline$* * . \wedge \wedge 1$ & الأعراض النفسية للتتمر \\
\hline$* * . \wedge .1$ & الأعراض المهنية للتتمر \\
\hline
\end{tabular}

يتضح من الجداول السابقة (r، r،، ؟) أن معاملات ارتباط مفردات مقياس أعراض

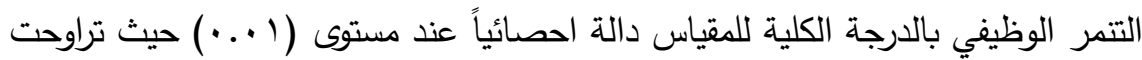

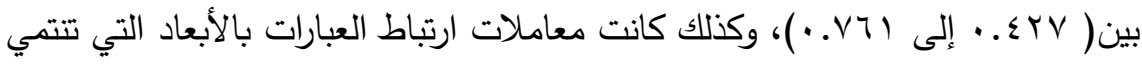

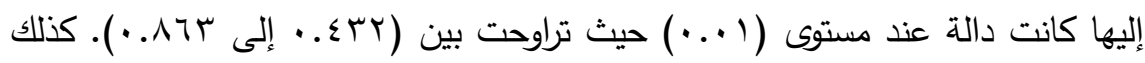

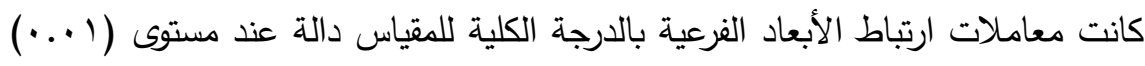

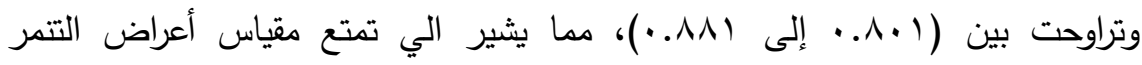
الوظيفي بالاتساق الداخلي. r- تم حساب ثبات ألفا كرونباخ والتجزئة النصفية، وفيما يلي النتائج التي تم التوصل إليها:

جدول(0) معاملات ثبات ألفا كرونباخ لأبعاد مقياس أعراض التتمر الوظيفي والدرجة الكلية

\begin{tabular}{|c|c|}
\hline معامل ثبات ألفا كرونباخ & الأبعاد \\
\hline$. \wedge \leqslant 9$ & الأعراض الجسمية للتتمر \\
\hline. .179 & الأعراض النفسية للتتمر \\
\hline. .174 & الأعراض المهنية للتتمر \\
\hline$\cdot .9 \cdot 1$ & الدرجة الكلية للدقياس \\
\hline
\end{tabular}




\section{أ.د. بشرى اسهاعيل احمد أرنوط}

جدول (7)

\begin{tabular}{|c|c|c|}
\hline \multicolumn{2}{|c|}{ معاملات ثبات التجزئة النصفية } & \multirow[t]{2}{*}{ 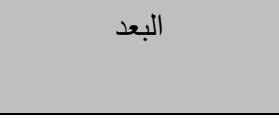 } \\
\hline جتمان & سبيرمان - براون & \\
\hline .211 &..$\vee \backslash 1$ & الأعراض الجسمية للتنمر \\
\hline $.7 \leqslant 1$ &. .747 & الأعراض النفسية للتنمر \\
\hline$\cdot v \cdot v$ & $. . V \leqslant \vee$ & الأعراض المهنية للتمر \\
\hline.$\vee \wedge 1$ & $. . \vee 9 \leqslant$ & الدرجة الكلية للمقياس \\
\hline
\end{tabular}

يتضح من الجدولين السابقين (0، 7) أن معاملات ثبات ألفا كرونباخ والتجزئة

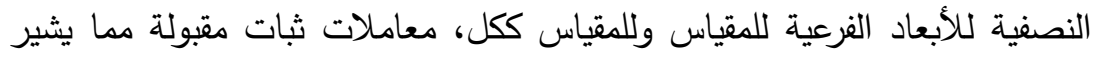

إلى ثبات مقياس أعراض التنمر الوظيفي.

مواد البحث: تمثلت مواد البحث في البرنامج الذي أعدته الباحثة والذي يقوم على العلاج

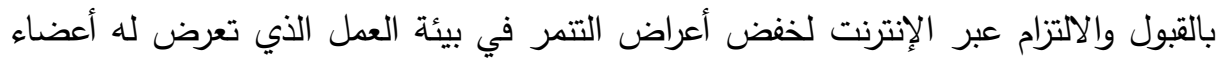
هيئة التدريس أفراد المجموعة التجريبية سواء كانت أعراض جسمية ونفسية ومهنية، وفيما يلي لئي شرح هذا البرنامج بالتقصيل:

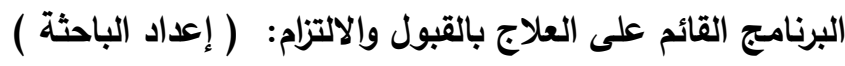

التخطيط العام للبرنامج: تضمن تخطيط البرنامج القائم على العلاج بالقبول والالتزام عبر التران الإنترنت عملية إعداد أهداف البرنامج العامة والخاصة وتحديد المدة الزمنية للبرنامج، وتحديد

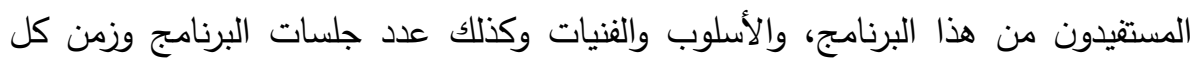
جلسة وعرض جدول ملخص لسير الجلسات والفنيات المستخدمة. مصادر بناء البرنامج: تم بناء هذا البرنامج بالاعتماد على الأطر النظرية والدراسات والأبحاث التي اهتمت بموضوع التتمر بصفة عامة، والتتمر في بيئة العمل بصفة خاصة التهاءة

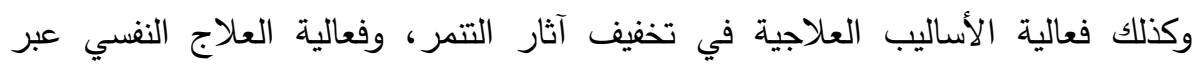

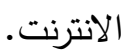

التصور النظري للبرنامج: من خلال الإطار النظري والدراسات السابقة تم وضع تصور نظري شامل للتتمر في بيئة العمل، والذي ساهم بشكل فعال في تحديد أهداف البرنامج وأنشطته المختلفة وذلك من خلال الآثار السلبية للتمر في بيئة العمل التي أوردها فرتيا

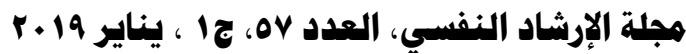




\section{فعالية برناهج قائم على العلاج بالقبول والإلترام عبر الانترنت}

(Vartia,2001)وهي: التسبب في المشكلات بين الموظفين، ضعف الإنتاجية، انخفاض الروح المعنوية وارتفاع دوران الموظفين، النتائج غير فعالة، ومستوى الأداء دون المستوى لئن المطلوب، ضعف الالتزام بالمبادئ التوجيهية للممارسة المهنية، الأخطاء المهنية والنتائج السلبية، فقدان المؤسسة لعملائها، الدعاوى أو الثكاوى الخاطئة والباطلة.

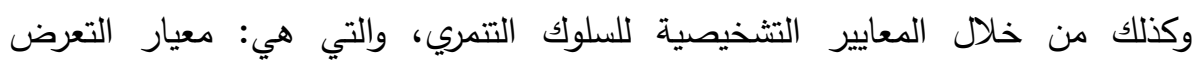
للصدمات النفسية، ومعيار أعراض الاختراق، ومعيار التجنب، ومعيار الإدراك والمشاعر هيل

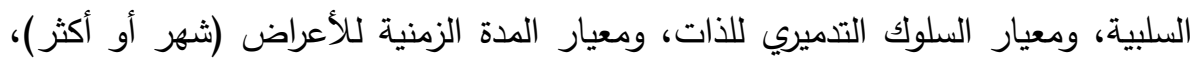

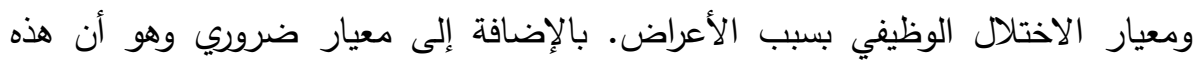

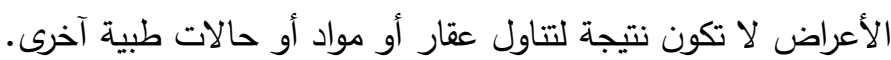

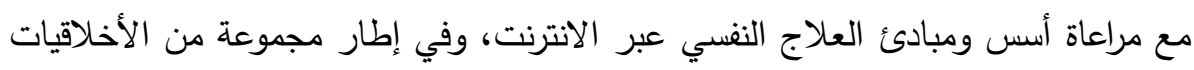
المهنية، إذ يتم فيه تقديم الخدمات العلاجية النفسية المباشرة وغير المباشرة المتتوعة

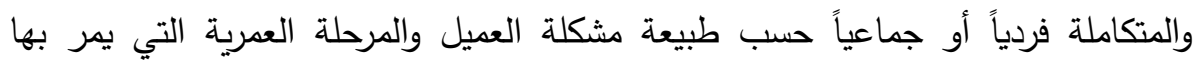
ومتطلبات النمو وتحدياته وقدراته الجسية والعقلية، وذلك باستخدام الفنيات التدخلية المناسبة بهدف مساعدته على حل مشكلاته وإحداث التغيير الإيجابي المطلوب في الجوانب السلوكية والمعرفية والاجتماعية، واستغلال قدراته وإمكاناته لتحقيق التوافق النفسي والسعادة الشخصية

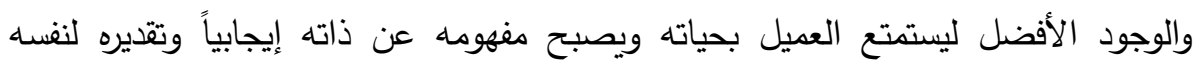
أعلى. ويعد العلاج بالقبول والالتزام هو علاج يعتمد على افتراض أن العديد من الأعراض التي

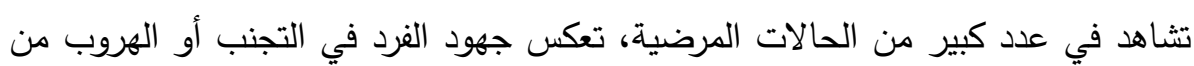
الانفعالات، والأفكار، والذكريات وغيرها من الخبرات الخاصة (Hayes etal,1996). كحالات سوء استخدام العقاقير، والتفكك، وسلوك إيذاء الذات، والسلوك التجنبي كلها

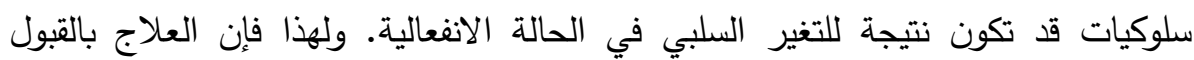
والالتزام استخدم في علاج الكثير من الاضطرابات والمشكلات الاكلينيكية، على سبيل

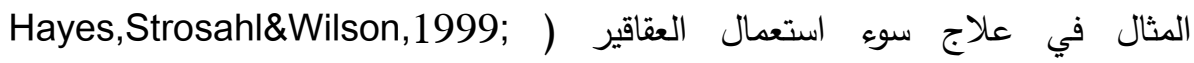
Marlatt,1994). وكذلك استخدم العلاج بالقبول والالتزام في علاج الأعراض الذهانية

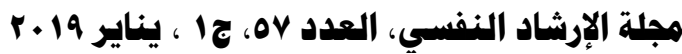




\section{أ. أد. بشرى اسماعيل احمد أرنوط}

(Bach\&Hayes,2002)، كما استخدم في علاج اضطراب القلق المعدم (Roemer\&Orilo,2002) .(Roemer\&Orsillo,2002) وتثير بعض الأدلة على أن العلاجات التي عرفت بالموجة الثالثة التي تضم اليقظة الذهنية والقبول، مثل العلاج بالقبول والالتزام العلاج (ACT)، هي تدخلات بديلة للعلاج السلوكي

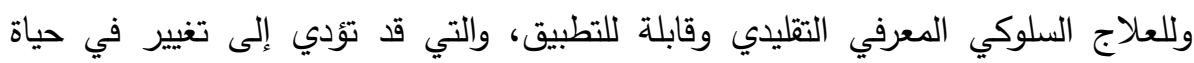
العملاء من خلال آليات فريدة من نوعها. فالعلاج القبول والالتزام لا يركز فقط على تخفيف الأعراض كنتيجة. بل يتم تشجيع العملاء

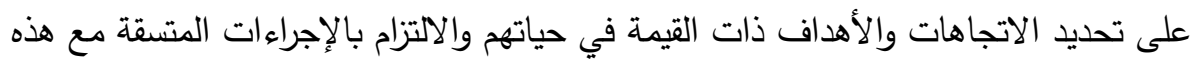
القيم. فالعلاج بالقبول والالتزام يهدف إلى تحسين العناصر الهامة في حياة العميل .(Kazdin,2004) الأسس التي يقوم عليها البرنامج: الأسس العامة: وتتمثل الأسس العامة في عدة مبادئ منها قابلية السلوك الانساني للتعديل

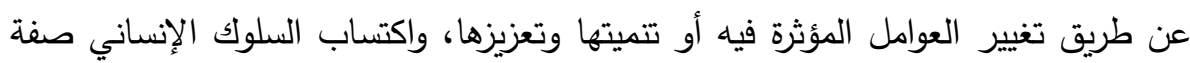
الثبات النسبي وإمكانية التتبؤ به، ومرونة السلوك الانساني فردي - جماعي، واستعداد الفرد للتوجيه والارشاد وحقه في التوجيه والارشاد، وحقه في تقرير مصيره، كذلك من الأسس وله

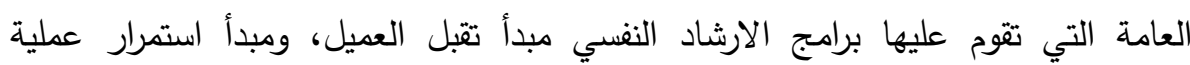

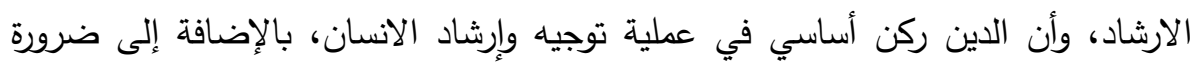

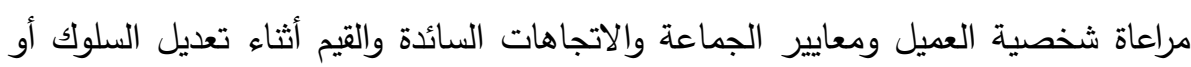
تتميته (زهران، 0 . . ب). الأسس الفلسفية: وهي مراعاة طبيعة الانسان، وأخلاقيات الارشاد النفسي، وكذلك الأسس

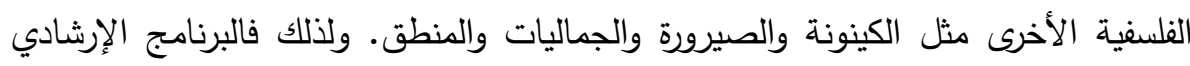

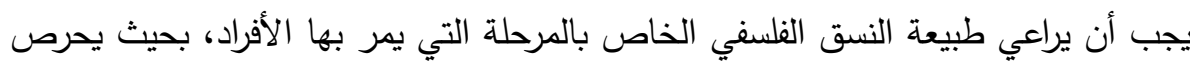

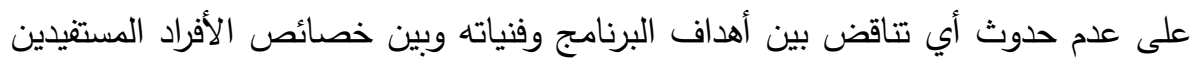
من البرنامج وأهدافهم في الحياة، التي تتمثل في رغبتهم أو رغبة المحيطين بهم في التغلب التبن على مشكلاتهم؛ وذلك للوصول إلى أفضل الوسائل التي تتاسب قدراتهم وإمكانياتهم رئ رعاه

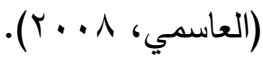

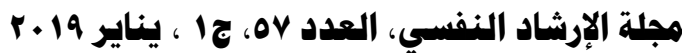




\section{فعالية برناهج قائم على العلاج بالقبول والإلتزام عبر الانترنت}

الأسس النفسية والتربوية تشير إلى مراعاة برامج الارشاد النفسي لثخصية العميل وللفروق

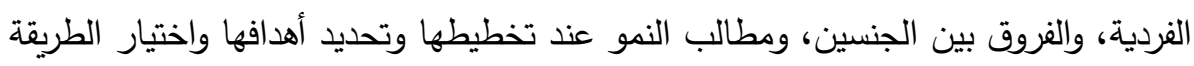

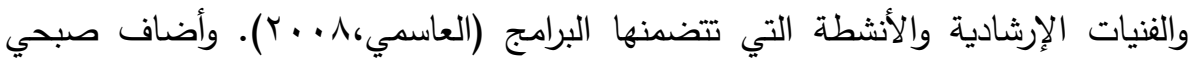

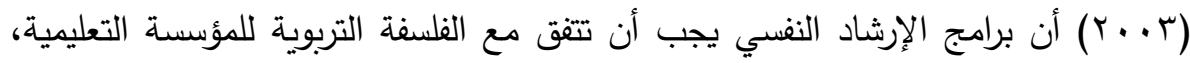

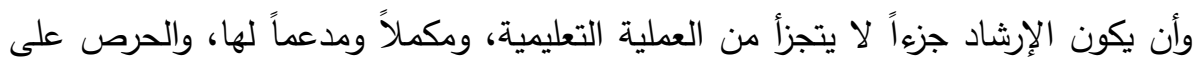

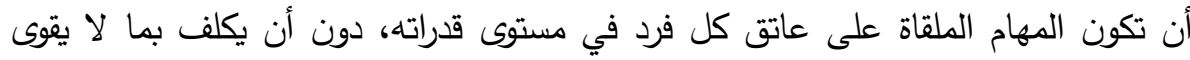
عليه.

الأسس الاجتماعية (Social Fundamentals): وتشير هذه الأسس إلى الاهتمام بالغرد

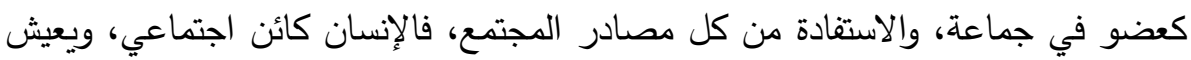

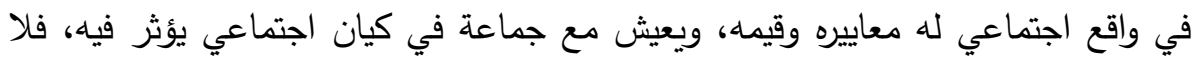

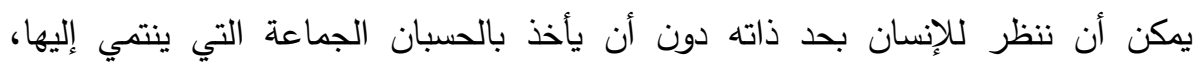

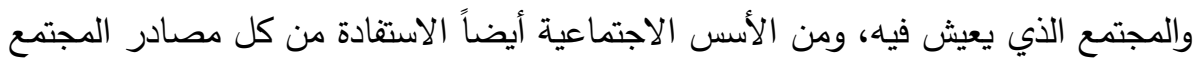

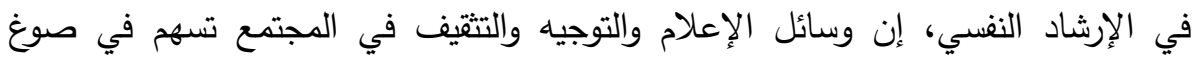
شخصية الفرد، والمؤسسة التعليمية لها دور كبير ومهم يمكن أن تسهم فيه من خلال تقديم الإني

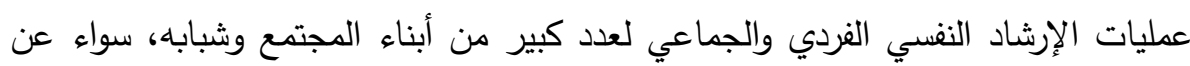

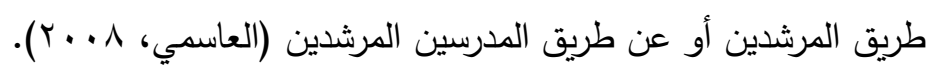

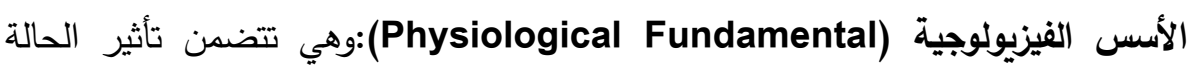

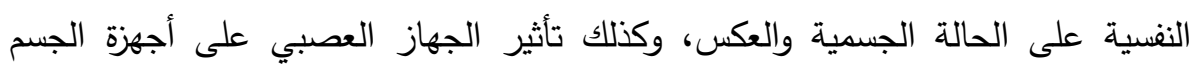

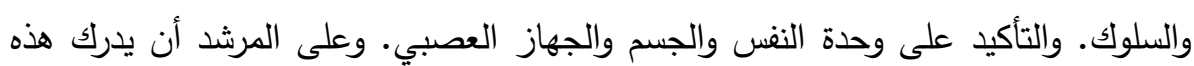

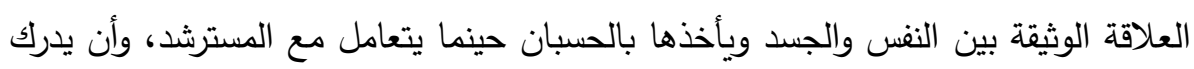

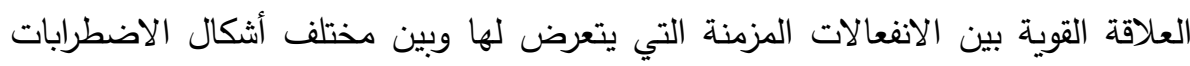

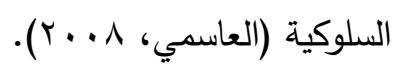
الأسس الإدارية (Administrative foundations): وتتمثل في دور المؤسسة التي تتفذ البرنامج الإرشادي في تهيئة الامكانات الادارية لتخطيط وتمويل وتنفيذ وتقييم البرنامج،

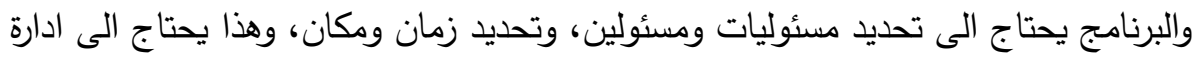

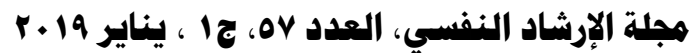




\section{أ.د. بشرى اسماعيل احمد أرنوط}

وإشراف ومتابعة لتتسيق الجهود، وتثجيع التعاون والحوافز للمسئولين عن البرنامج

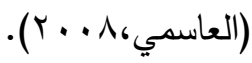

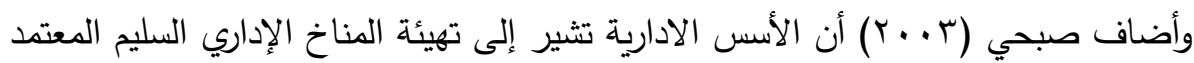

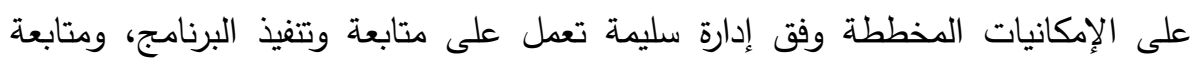

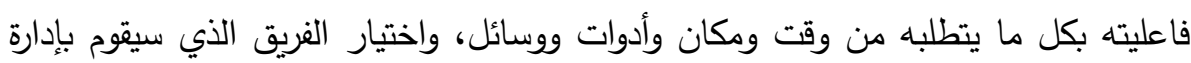
البرنامج، بحيث يتميز الفريق بكافة الصلاحيات التي من شأنها أن تساعدهم على إدارة العمل مع مراعاة تميزهم بالقيم الدينية والأخلاقية والفنية والجمالية. المبادئ التي يجب مراعاتها عند تنفيذ الجلسات التدخلية:

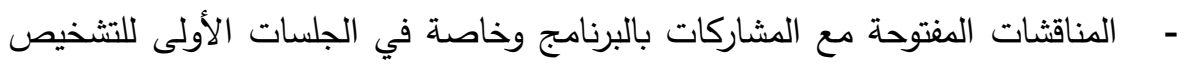
التكاملي للمشكلة والمساهمة في تحديد الأهداف.

- - التغذية الراجعة من خلال مراجعة ما تم في الجلسة السابقة مع المشاركات بالبرنامج.

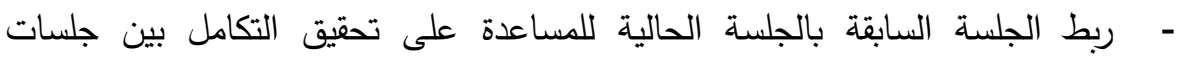

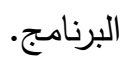

ت تعليم المشاركات بالبرنامج الفنية الجديدة والتدريب عليها وشرحها ليستوعبها مع مراعاة التترج في التدريب حتى لا يصاب المسترشد باليأس والملل والاحباط.

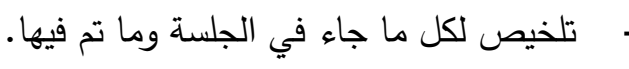
- - تقييم المشاركات بالبرنامج للجلسة وما تم فيها ومقدار استفادته منها وتحقيقها لأهدافه، ومقترحاته حول الجلسات القادمة. - تقديم الباحثة واجبات منزلية للمشاركات بالبرنامج في كل جلسة بما يرتبط مع مشاكلهن ويكون له دور فعال في خفضها والتغلب عليها.

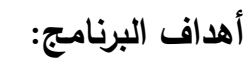

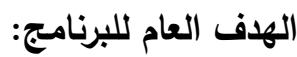
خفض أعراض التتمر الوظيفي، وزيادة اتصال المشاركات بالبرنامج بحاضرهن وباللحظة

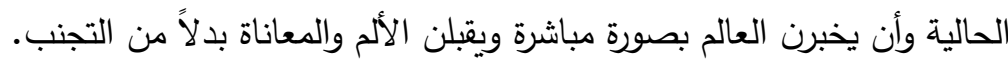




\section{فعالية برنامج قائم على العلاج بالقبول والإلتزام عبر الانترنت}

الأهداف الإجرائية للبرنامج:

1- أن تتعرف المشاركات بالبرنامج على مفهوم التتمر في بيئة العمل، وصوره وأنماطه

$$
\text { وأسبابه. }
$$

ז- أن تتعرف المشاركات بالبرنامج على آثار التتمر واعراضه على مستوى الفرد وعلى

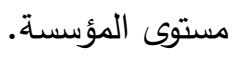

r- أن تدرك المشاركات بالبرنامج متى يكون قد وقعن ضحية للسلوك التتمري وماذا

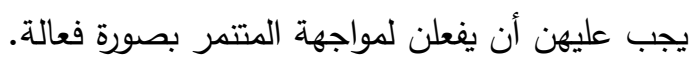

ع- أن تتدرب الدشاركات بالبرنامج على قبول البيئة التي يعملن فيها بإيجابياتها وسلبياتها.

0- أن تتدرب الششاركات بالبرنامج على إدراك ذاتهن كسياق منفصل عن الثعور

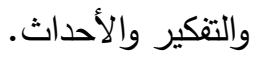
7- - أن تتدرب المشاركات بالبرنامج على الإدراك السليم للأحداث والمواقف. - V أن تتدرب المشاركات بالبرنامج على مراجعة وتتييم أفكارهن.

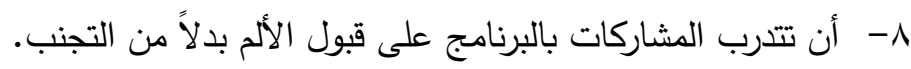
9- أن تتدرب المشاركات بالبرنامج على الثقة بالنغس.

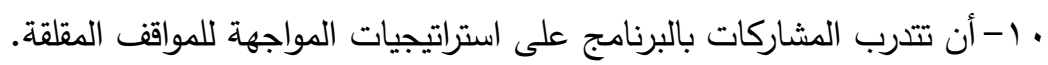
1ا-1أن تتدرب الششاركات بالبرنامج على أن يخبرن العالم بصورة مباشرة لزياديادة

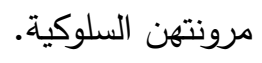

r ا ا أن تتدرب المشاركات بالبرنامج على الوعي بالخبرات المتدفقة دون سيطرة عليها.

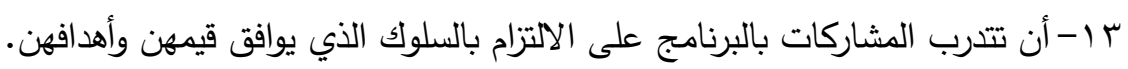

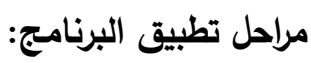

$$
\text { 1-مرحلة التهيئة (البداء والتحضير للبرنامج): }
$$

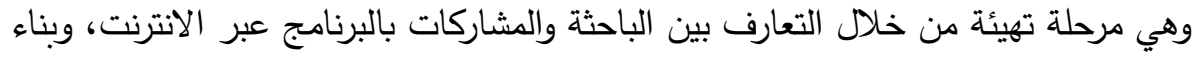

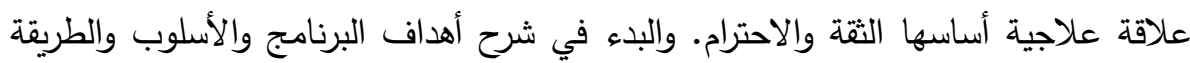

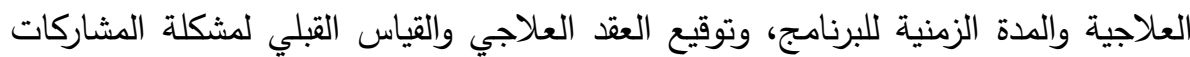
بالبرنامج كخط قاعدي ينطلق منه البرنامج. وتتمثل هذه المرحلة في الجلسة الأولى.

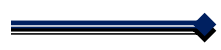




\section{أ.د. بشرى اسماعيل احمد أرنوط}

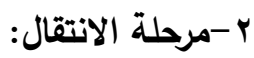

فيها يتم تقديم خلفية معرفية نظرية للمشاركات بالبرنامج عن مشكلتهن وأسبابها ومظاهرها وذلك لإلقاء الضوء على المشكلة الأساسية وهي التتمر وخفض أثاره السلبية والتخلص منها وتمثلها الجلسات الثانية والثالثة والرابعة.

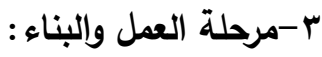
وهي مرحلة تغيير وتعديل سلوك المشاركات بالبرنامج والأثار السلبية المترتبة على وقوعهن ضحية للتمر من خلال تطبيق الفنيات التذخلية وممارسة أنشطة البرنامج بشكل فردي ذاتئي لخفض معاناتهن وشعورهن بالألم، وتمثلها الجلسات من الجلسة الخامسة إلى الحادية عشر .

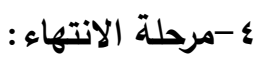
وهي المرحلة قبل النهائية للبرنامج والتي تهدف إلى التأكد من تحقيق أهداف البرنامج

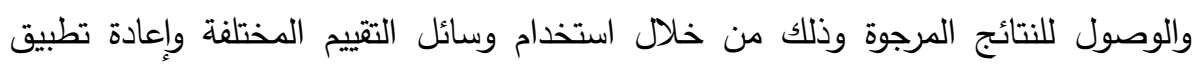
أدوات البحث لمعرفة فعالية البرنامج على المشاركات بالبرنامج، من خلال مقارنة نتائج

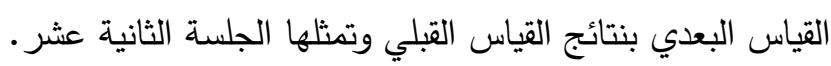

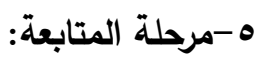

وهي المرحلة الأخيرة والنهائية حيث يتم في هذه المرحلة التحقق من استمرارية النتائج

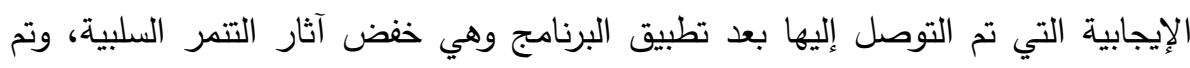
ذلك من خلال تطبيق مقياس التتمر في بيئة العمل بعد مرور شهر ونصف تئس من انتهاء البرنامج وتطبيق القياس البعدي، ثم تقارن نتائج القياس التتبعي بنتائج القياس البعدي وفي فئي

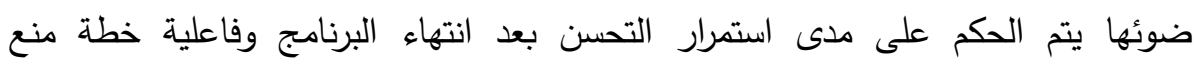
الانتكاسة.

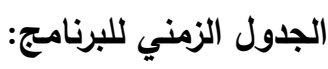
تكون البرنامج الذي تم تصميمه من أثنى عشر (Y l ( ) جلسة عبر الإنترنت من خلال برنامج Skype وقد استمر تتفيذه على مدى ست أسابيع (شهر ونصف) بواقع جلستان أسبوعياً،

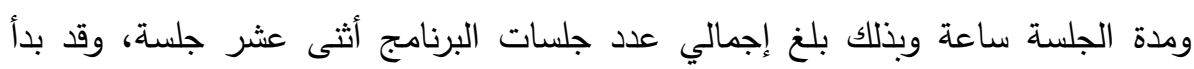

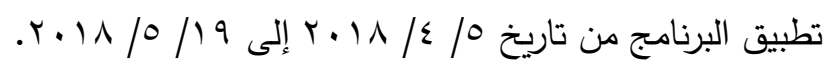

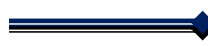




\section{فعالية برناههج قائم على العلاج بالقبول والإلترام عبر الانترنت}

الفئة المستهدفة للبرنامج:

عضوات هيئة التدريس اللاتي تعرضن للتمر في بيئة العمل وحصلن على درجات مرتفعة في مقياس أعراض التتمر الوظيفي( إعداد الباحثة). الطريقة والأسلوب والفنيات المستخدمة في البرنامج: طبقت الباحثة البرنامج القائم على العلاج بالقبول والالتزام بصورة فردية على أفراد المجموعة التجريبية للبحث عبر الإنترنت من خلال برنامج Skype، وذلك بهدف خفض الآثار السلبية المترتبة على التعرض للتنمر في بيئة العمل. ولذلك استخدمت الفنيات التالية: المحاضرة، بلتهبه الحوار والنقاش، الواجب المنزلي، التعزيز، التغذية الراجعة، النمذجة، التعرض، التبول،

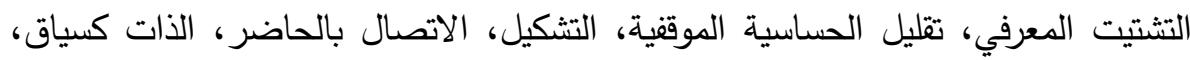
تحديد الأهداف، تحديد القيم واختيارها، الالتزام والإصرار • وذلك من خلال ثلاثة جوانب رئيسة، تم مراعاتها أثناء تتفيذ البرنامج لتحقيق أهدافه وهو

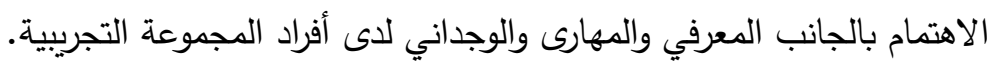

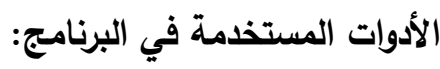
استمارة تقويم الجلسة - استمارة تقييم البرنامج- مقياس التتمر في بيئة العمل- استمارات

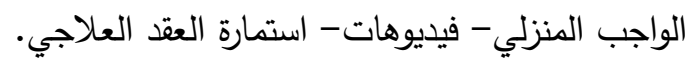
تقويم البرنامج: تم تقويم البرنامج من خلال الاجراءات التالية: 1- القياس القبلي بتطبيق مقياس أعراض التتمر الوظيفي لتحديد درجة مشكلة أفراد المجموعة التجريبية. r- القياس البعدي بعد انتهاء تتفيذ كافة جلسات البرنامج عبر الإنترنت وذلك للتعرف

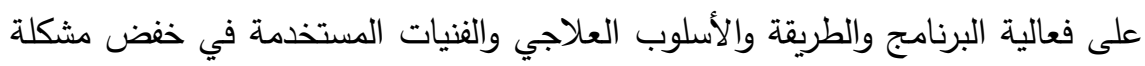
العميل والتغلب عليها من خلال مقارنتها بدرجة المشكلة في مرحلة القياس القبلي. r- القياس التتبعي للكثف عن استمرار وبقاء أثر البرنامج بأنشطته وفنياته ومنع

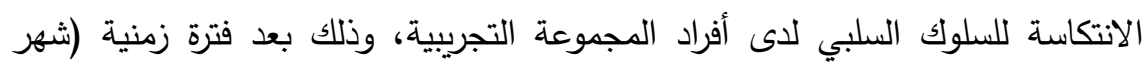
ونصف) من انتهاء تطبيق البرنامج عبر الإنترنت بإعادة تطبيق مقياس التتمر في بيئة العمل على أفراد المجموعة التجريبية في البرنامج.

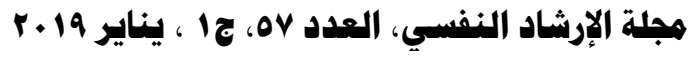




\section{أ.د. بشرى اسماعيل احمد أرنوط}

$$
\text { تقيتم تقويم البرنامج في عدة مراحل، هي: }
$$

من خلال تطبيق مقياس أعراض التتمر الوظيفي على أفراد المجموعة التجربيية، وكان ذلك

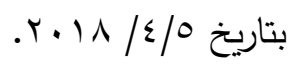$$
\text { تقويم مرحلي: }
$$

أثثاء تتفيذ البرنامج عبر الإنترنت وخلال جلساته التخلية، حيث لا يتم الانتقال من نشاط

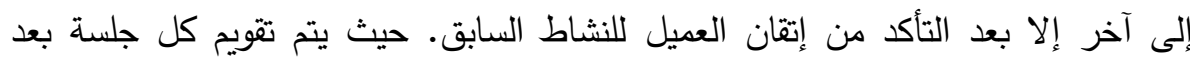

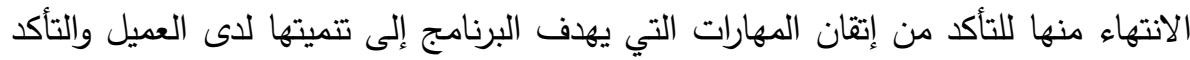

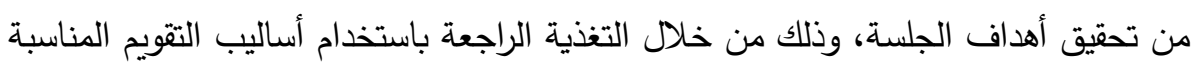
من ملاحظة التغير في سلوك العميل واستمارات تقويم الجلسة. تقويم ختامي: تمن ماحكه ويتم ذلك في الجلسة الأخيرة من البرنامج بعد الانتهاء مباشرة من تطبيق كافة جلساته

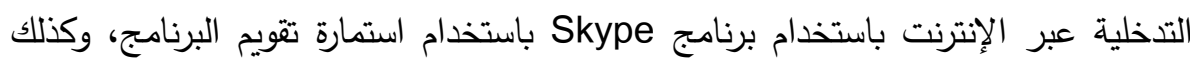

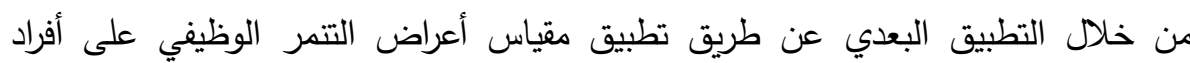
المجموعة التجريبية، وكان ذلك بتاريخ 9 / / م/ م 1 ـ ـ. تقويم تتبعي:

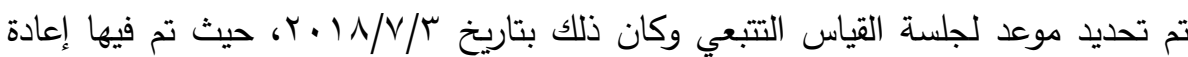
تطبيق مقياس أعراض التتمر الوظيفي على أفراد المجموعة التجريبية بعد مضي شهر

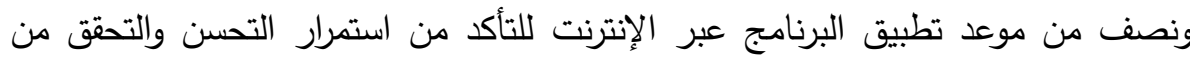

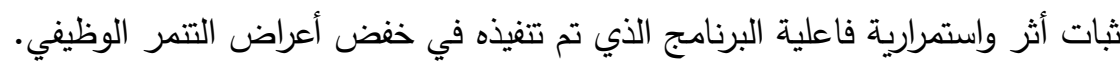




\section{فعالية برناههج قائم على العلاج بالقبول والإلترام عبر الانترنت}

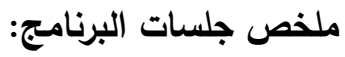

جدول (v)

ملخص لجلسات البرنامج القائم على العلاج بالقبول والالتزام عبر الإنترنت لخفض أعراض التنمر الوظيفي

\begin{tabular}{|c|c|c|c|}
\hline الفنيات & الأهداف & عنوان الجلسة & رقم الجلسة \\
\hline الحواض والنقاش & 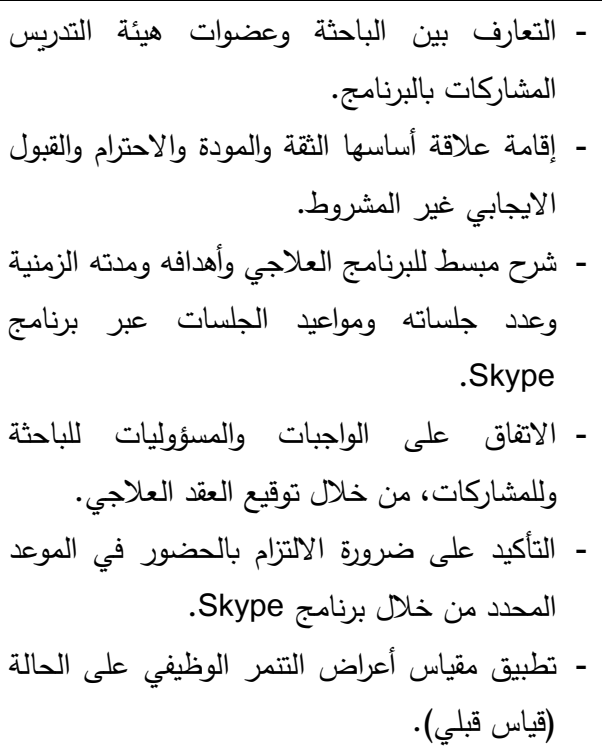 & تمهيد وتعارف & الأولى \\
\hline التحوار والنقاش & 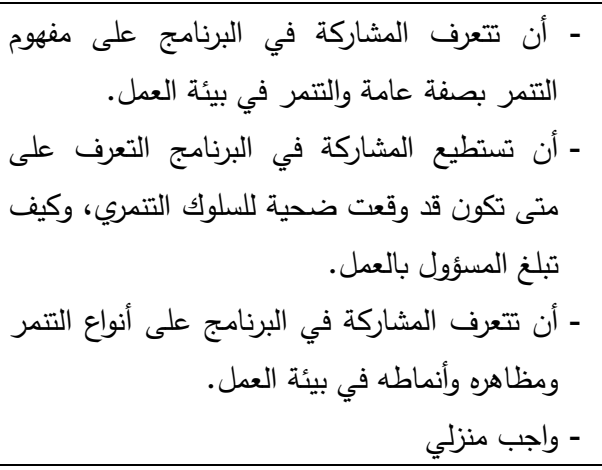 & العمل آفة العصر في بيئة & الثانية \\
\hline 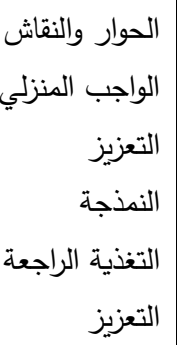 & 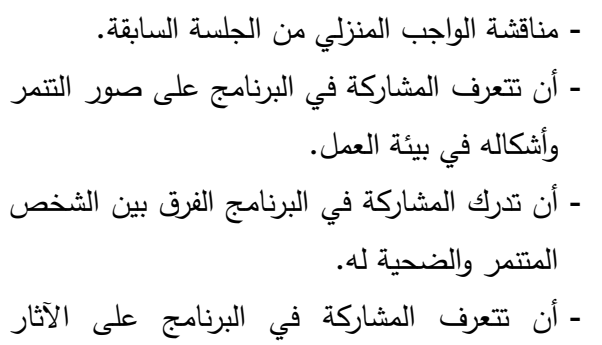 & للت لا تكوني ضحية & الثالثة والرابعة \\
\hline
\end{tabular}

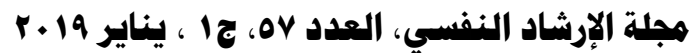

$(r\urcorner)$ 


\section{أ.د. بشرى اسماعيل احمد أرنوط}

\begin{tabular}{|c|c|c|c|}
\hline & 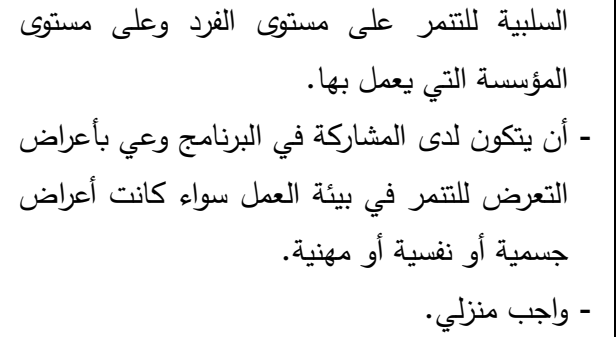 & & \\
\hline التاجب التعوار والنقاش التنزبي & 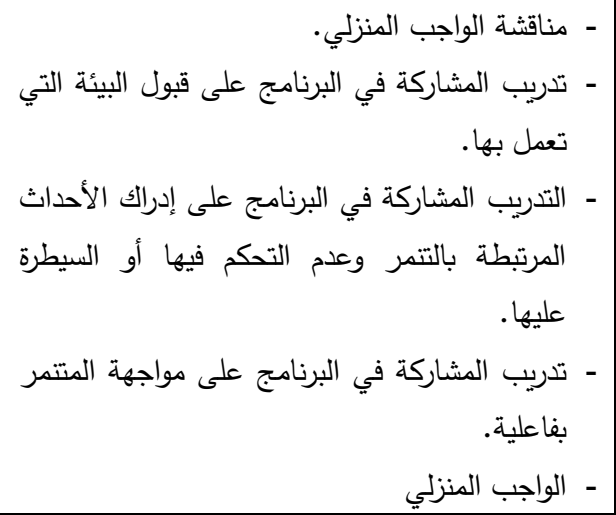 & كوني عتلاقة ولا & والخامسة \\
\hline التقاجب التقار والنقاش. & 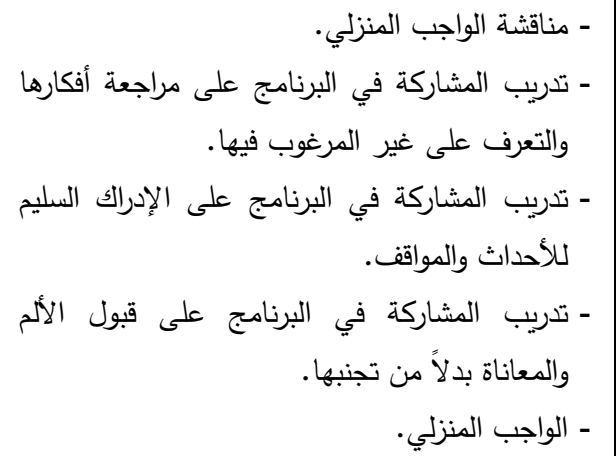 & لا ت تربطي أفكارك & البابعة \\
\hline 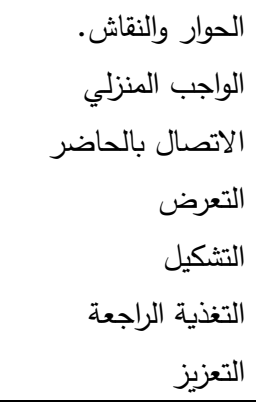 & 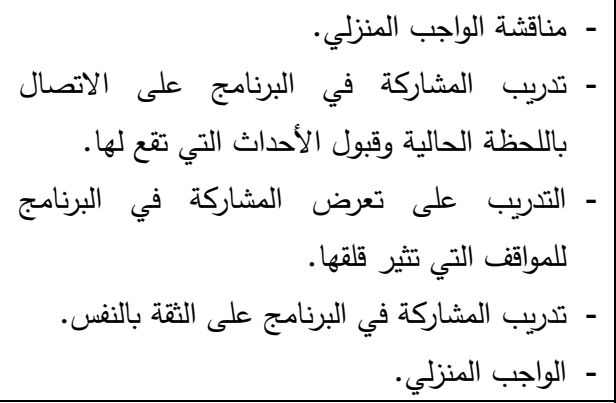 & وفوني & التاسعة \\
\hline الحوار والنقاش & - - مناقثة الواجب المنزلي. & كوني أكثر مرونة & العاشرة \\
\hline
\end{tabular}




\section{فعالية برناهج قائم على العلاج بالقبول والإلترام عبر الانترنت}

\begin{tabular}{|c|c|c|c|}
\hline التالتب التعزيز التنزلي & 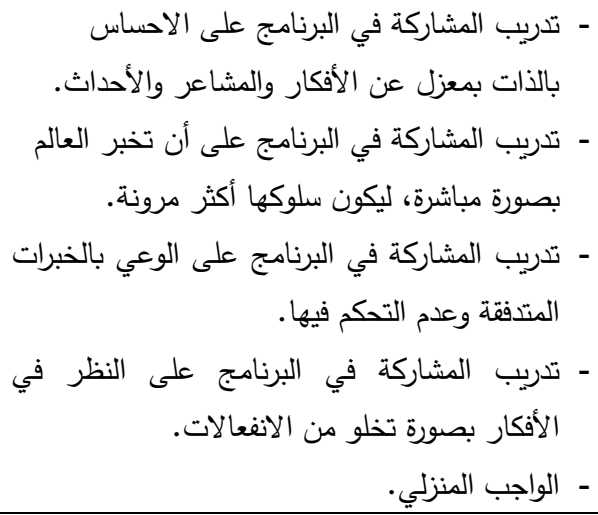 & & \\
\hline 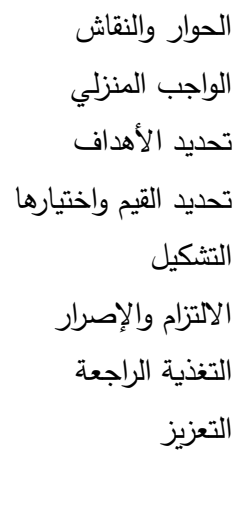 & 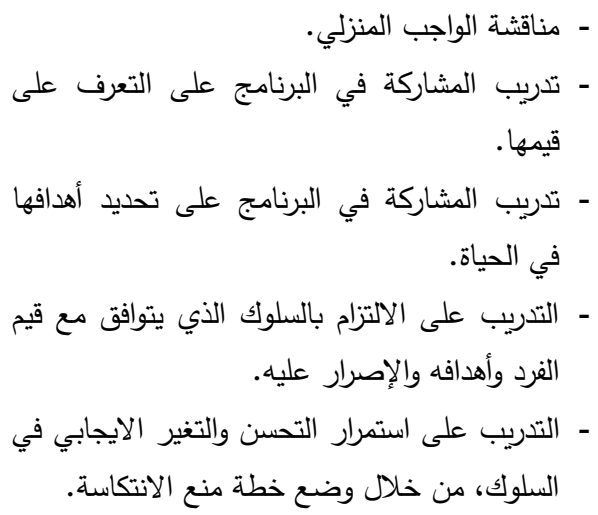 & واختاري أهدافك قديك & الحادية عشر \\
\hline التعزار والنقاش التغزية التراجعة & 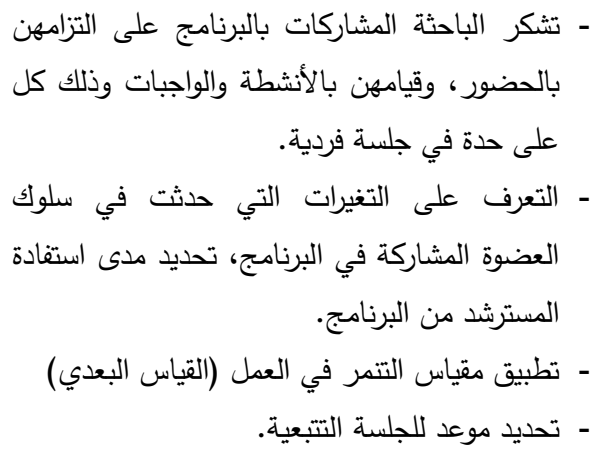 & التقييم والانهاء & الثانية عشر \\
\hline
\end{tabular}

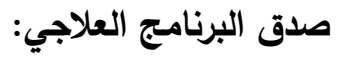

بعد تحديد موضوعات الجلسات العلاجية، قامت الباحثة بتصميم البرنامج القائم على العلاج بالقبول عبر الإنترنت والالتزام بالصيغة الأولية، ثم قامت بعرضهات على مجموعة من الخبراء 


\section{أ.د. بشرى اسماعيل احمد أرنوط}

المتخصصين في مجال الإرشاد والعلاج النفسي، وذلك للحكم على ملائمة التصميم للبرنامج

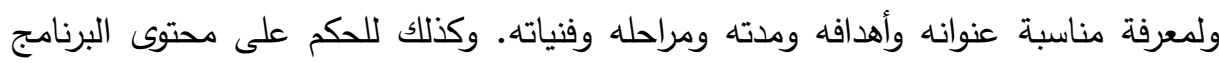

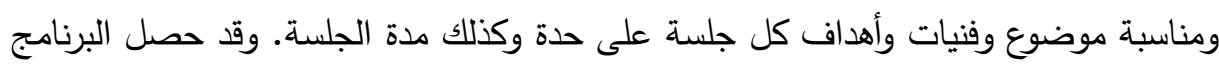

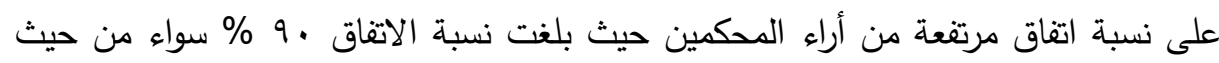

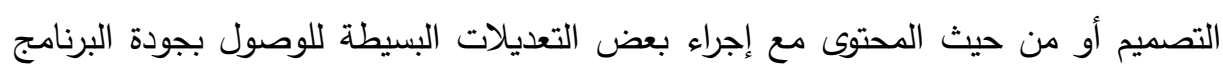

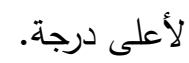

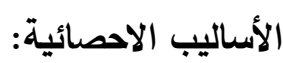

من اجل تحليل نتائج البحث وفقاً لأهدافها وفروضها، استخدمت الباحثة الأساليب التالية:

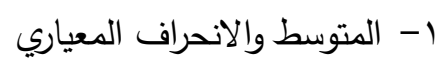
r- بـ الماملا الالتواء والتترطح لاختبار اعتدالية التوزيع. r- اختبار " ت " T test لدراسة دلالة الفروق لدجموعتين مستقلتين ومجموعتين مترابطين بعد التحقق من اعتدالية التوزيع.

\section{نتائج البحث وهناقشتها وتفسيرها:}

قامت الباحثة بتلخيص نتائج البحث الحالي من خلال التحقق من الفروض باستخدام

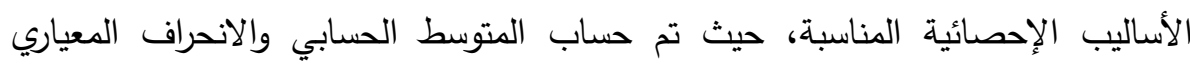

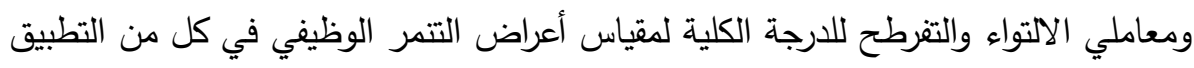

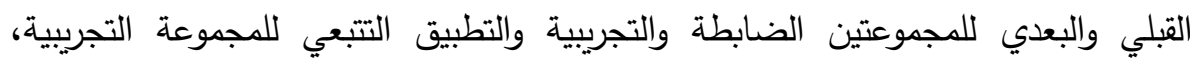

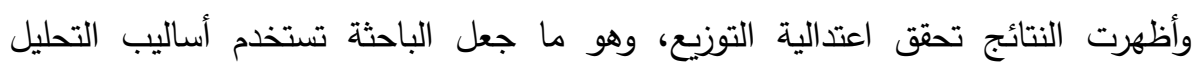
الإحصائي البارامتري في التحقق من فروض البحث، والجدول التالي يوضح النتائج:

جدول (^)

المتوسط الحسابي والانحراف المعياري ومعاملا الالتواء والتترطح للدرجة الكلية لمقياس أعراض التتمر الوظيفي في كل من التطبيق القبلي

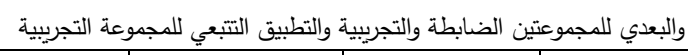

\begin{tabular}{|c|c|c|c|c|c|}
\hline معامل التفرطح & معامل الالتواء & الانحراف المعياري & المتوسط الحسابي & المجموعة & التطبيق \\
\hline$-1.1 \leqslant 1-$ &..$\leqslant T V$ & V. $\leqslant \wedge t$ & אד.4 & الضابطة & \multirow[t]{2}{*}{ القبلي } \\
\hline $1.7 .1-$ & $.199-$ & $\Lambda .7 \leqslant \Lambda$ & $9 . .7 \leqslant 1$ & التجريبية & \\
\hline$-1.1 \leqslant 1-$ &..$\Sigma T V$ & $V . \varepsilon \wedge r$ & גד.Tr & الضابطة & \multirow[t]{2}{*}{ البعدي } \\
\hline 1.1 .9 & $-. .979-$ & $0 . r 94$ & $\varepsilon V_{\text {V. }}$ & التجريبية & \\
\hline 1.1 .9 & $-1 . . V r-$ & $7 . r \leqslant V$ & $\leqslant \vee .0$. & التجريبية & التتبعي \\
\hline
\end{tabular}

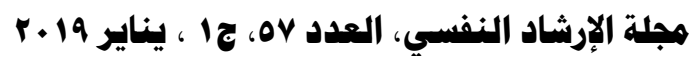




\section{نعالية برناهج قائم على العلاج بالقبول والإلترام عبر الانترنت}

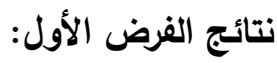
ينص الفرض الأول للبحث على: "توجد فروق ذات دلالة إحصائية بين متوسطي درجات المجموعتين الضابطة والتجريبية في مقياس أعراض التنمر الوظيفي بعد تطبيق البرنامج داله

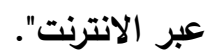
قامت الباحثة بالتحقق من فرض البحث الأول باستخدام اختبار ( ت) لمجموعتين مستقلتين

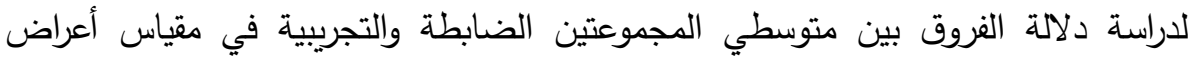

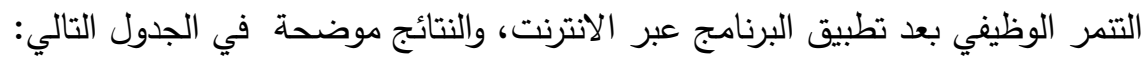
جدول (9) اختبار (ت) لدراسة دلالة الفروق بين متوسطي درجات الدجموعتين الضابطة والتجريبية في أعراض التنمر

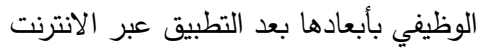

\begin{tabular}{|c|c|c|c|c|c|c|}
\hline مستوى & قيمة (ت) & الانحراف & المتوسط & ن & الدجموعة & البعد \\
\hline الدلالة & ودلالتها & المعياري & & & & \\
\hline \multirow[t]{2}{*}{ دالة } & \multirow[t]{2}{*}{$* * 11 . .4$ ג } & V.乏AT & זד.דה & $\wedge$ & الضابطة & \\
\hline & & 0.799 & $\{\Lambda .1 \leqslant$ & $\wedge$ & التجربية & \\
\hline
\end{tabular}

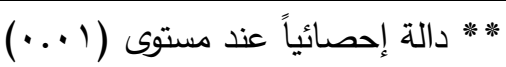

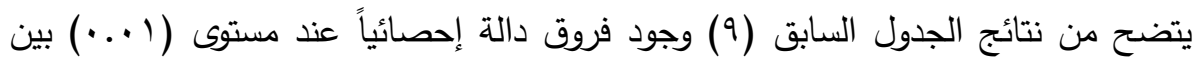

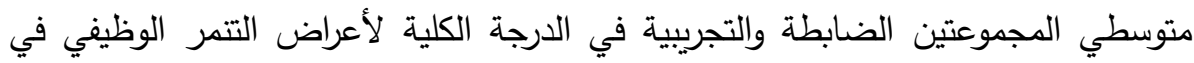
التطبيق البعدي عبر الإنترنت لصالح الدجموعة التجريبية.

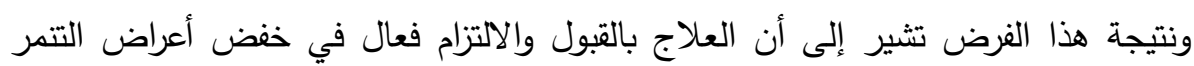

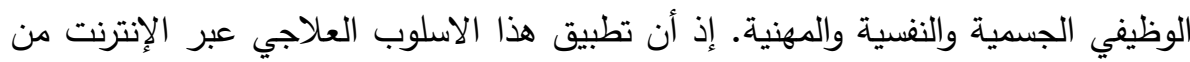

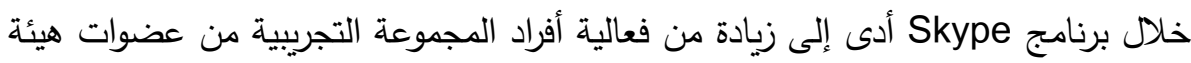

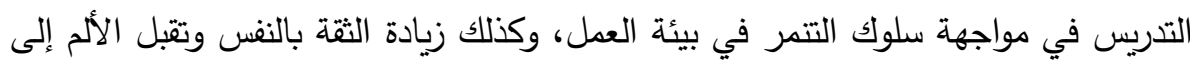

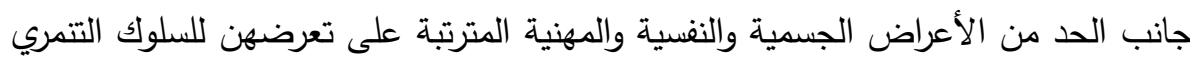

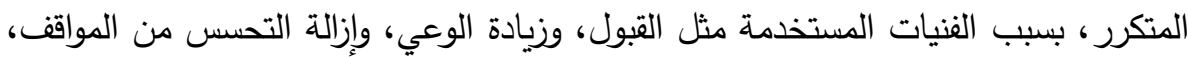
والعيش في الوقت الحاضر، ومراقبة ما يحدث دون اصدار أحكام، والمواجهة والالتزام

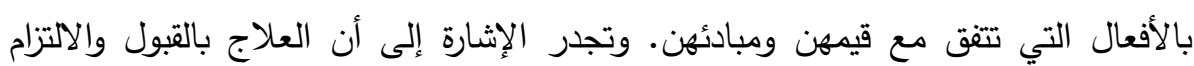

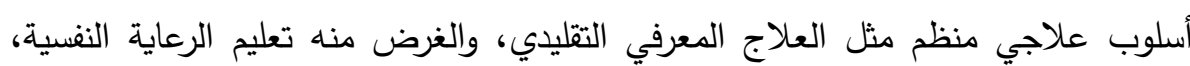

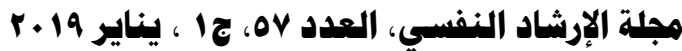




\section{أ.د. بشرى اسماعيل احمد أرنوط}

ليس لتغيير محتوى الأفكار فقط، بل الهذف هو خلق موقف أو تغيير العلاقة بين الأفكار

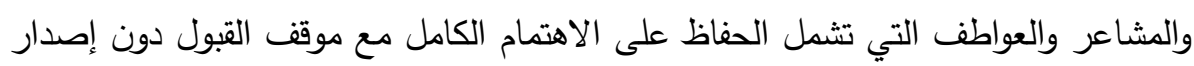
حكم. وانصب تركيز جلسات العلاج بالقبول والالتزام ACT عبر الإنترنت في هذا البحث على فئ

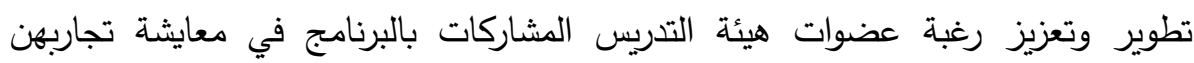

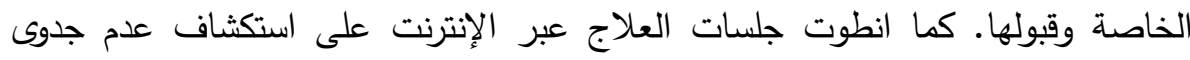

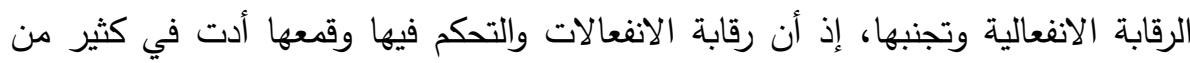

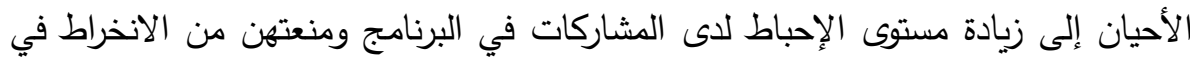

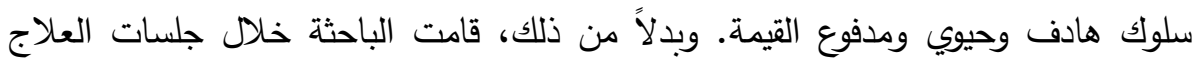

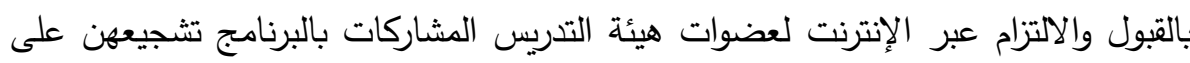

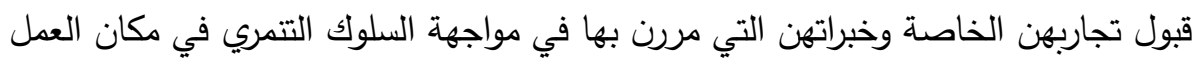

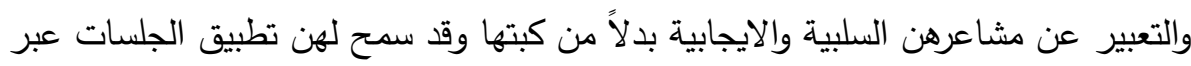

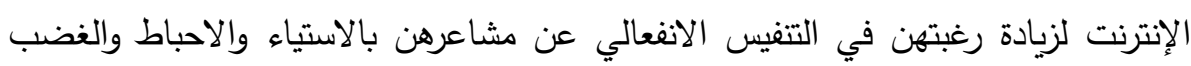
تجاه المتنمرين لهن، مما ساعدهن بعد ذلك على الانفي التخراط في سلوكيات إيجابية مرتبطة بقيمهن والتزام قيامهن بها.

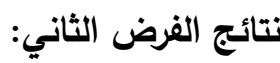
ينص الفرض الثاني على:" توجد فروق ذات دلالة إحصائية بين متوسطي درجات التئي

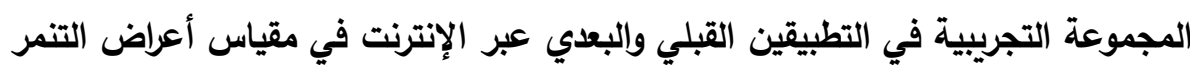

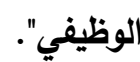
قامت الباحثة بالتحقق من فرض البحث الثاني باستخدام اختبار (ت) لمجموعتين مرتبطتين لدراسة دلالة الفروض بين متوسطي درجات المجموعة التجريبية في التطبيقين

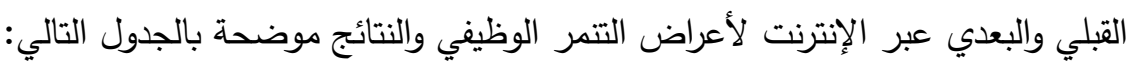

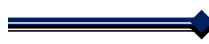

$(r)$ 


\section{فعالية برنامج قائم على العلاج بالقبول والإلتزام عبر الانتزنت =}

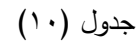

اختبار (ت) لدراسة دلالة الفروق بين متوسطي درجات الدجموعة التجريبية في التطبيقين القبلي والبعدي عبر الإنترنت

\begin{tabular}{|c|c|c|c|c|c|c|}
\hline \multicolumn{7}{|c|}{ لأعراض التتمر الوظيفي } \\
\hline مستوى الدلالة & قديمة (تلالتها & المعياري & المتوسط & ن & التطبيق & البعد \\
\hline \multirow[t]{2}{*}{ دالة } & \multirow[t]{2}{*}{$* * 11 . \leqslant .0$} & $\Lambda .7 \leqslant \wedge$ & $9 . . \vee 0$ & $\wedge$ & القبلي & \multirow{2}{*}{ أعراض التتمر } \\
\hline & & $0 . r 94$ & $\varepsilon \vee . V_{0}$ & $\wedge$ & البعدي & \\
\hline
\end{tabular}

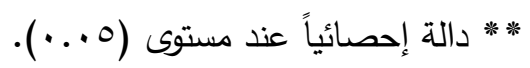

يتضح من نتائج الجدول السابق( • () وجود فروق دالة إحصائياً عند مستوى (1 (...) بين متوسطي درجات المجموعة التجريبية في التطبيقين القبلي والبعدي عبر الإنترنت في أعراض التتمر الوظيفي لصالح التطبيق البعدي. وهذه النتيجة تشير إلى فعالية البرنامج القائم على العلاج بالقبول والالتزام عبر الإنترنت في

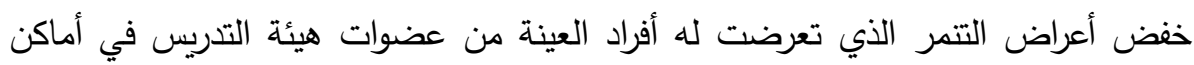

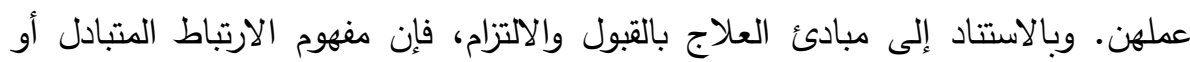

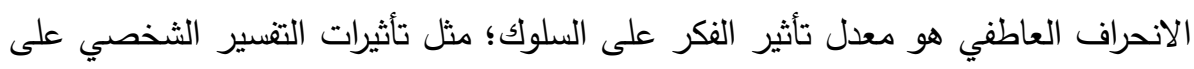

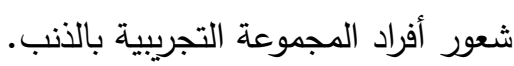

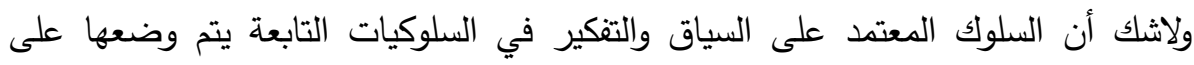
متصل بين الترابط أو الانحراف الانفعالي. فعندما يمتزج الشخص مع أفكاره، فإنه لا يميز بين حكمه الذاتي والواقع. وبالتالي، فإن تدريب أفراد المجموعة التجريبية من عضوات هئرات هيئة

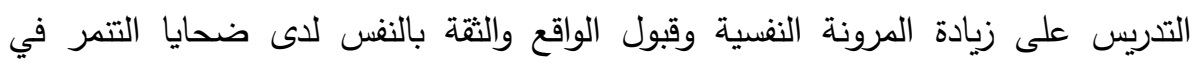

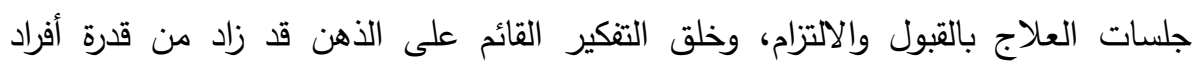

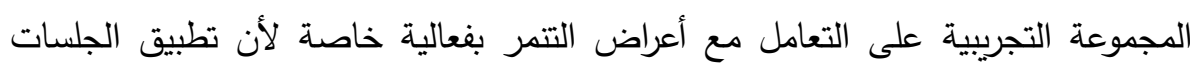
عبر الإنترنت اتاح لهم حرية التعبير عن مشاعرهن وانفعالاتهم دون قيود، وذلك بعد اتباع التعاله نظام تم الاتفاق عليه بين الباحثة وأفراد المجموعة التجريبية والتدريب عليه أثناء الجلسات. وهذا يتفق مع ما توصلت إليه نتائج الدراسات السابقة حول فعالية العلاج بالقبول والالتزام في علاج القلق والاكتئاب وخفض الاضطرابات النفسية وعلاج مشكلات العلاقات الشخصية وزيادة 


\section{أ.د. بشرى اسماعيل احمد أرنوط}

(Narimani,Pourbdor\&Bashirpour,2004;Karlinetal,2013;Azadeh,Zahrani \&Besharat,2016;Lang ｅtal,2017;Towsyfyan\&Sabet,2017;Heyedari etal.,2018)

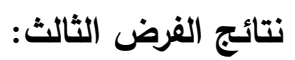

ينص الفرض الثالث على: "لا توجد فروق ذات دلالة إحصائية بين متوسطي درجات المجموعة التجريبية في التطبيقين البعدي والتتبعي عبر الإنترنت في أعراض التنمر

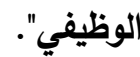

تم التحقق من هذا الفرض باستخدام اختبار (ت) لمجموعتين مرتبطتين لدراسة دلالة الفروض بين متوسطي درجات المجموعة التجريبية في التطبيقين القبلي والبعدي عبر منربين

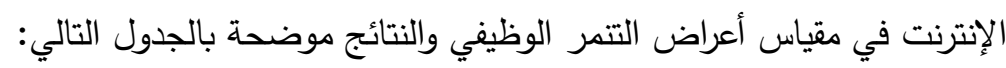

جدول (11)

اختبار (ت) لدراسة دلالة الفروق بين متوسطي درجات المجموعة التجريبية في التطبيقين البعدي والتتبعي عبر

\begin{tabular}{|c|c|c|c|c|c|c|}
\hline \multicolumn{7}{|c|}{ الإتترنت لأعراض التتمر الوظيفي } \\
\hline 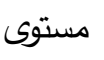 & قيمة (ت)، & الانحراف & المتوسط & ن & التطبيق الت & 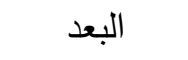 \\
\hline 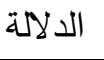 & ود لالتها & المعياري & & & & \\
\hline 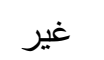 &..$Y \wedge \varepsilon$ & $0 . r 9 r$ & $\varepsilon \vee . \vee 0$ & $\wedge$ & البعدي & أعراض التتمر \\
\hline دالة & & $7 . r \leqslant V$ & $\leqslant V .0$. & $\wedge$ & التتبعي & 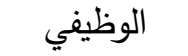 \\
\hline
\end{tabular}

يتضح من نتائج الجدول السابق (1/) عدم وجود فروق دالة إحصائياً بين متوسطي درجات المجموعة التجريبية في التطبيقين البعدي والتتبعي عبر الإنترنت في أعراض التبنمر تثير نتائج الفرض الثالث إلى استمرار التحسن لدى أفراد المجموعة التجريبية وبقاء أثر البرنامج الذي تم تطبيق جلساته أونلاين عبر برنامج Skype. وبطبيعة الحال، فإن تحسن

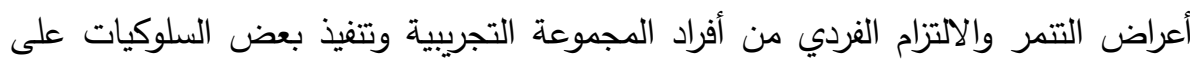
المدى الطويل من شأنه أن يزيد من السلامة النفية لهم، بل ويستطيعون مواجهة سلوكيات التتمر في العمل بكل فعالية وإيجابية فيما بعد. 


\section{فعالية برناهج قائم على العلاج بالقبول والإلتزام عبر الانترنت}

وتعزو الباحثة هذه النتيجة إلى الأثر الإيجابي الذي أحدثه البرنامج عبر الإنترنت القائم على

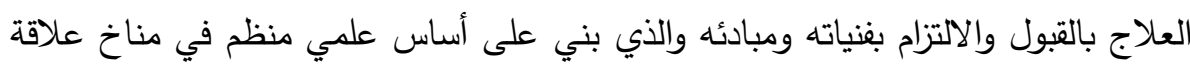

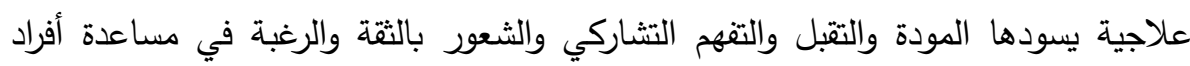
المجموعة التجريبية اللاتي يعانين من أعراض التتمر الوظيفي الجسمية والنفسية والمهنية.

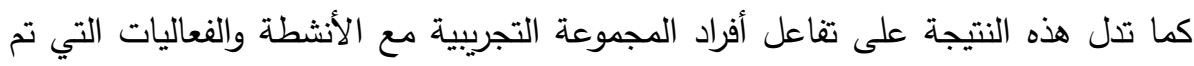

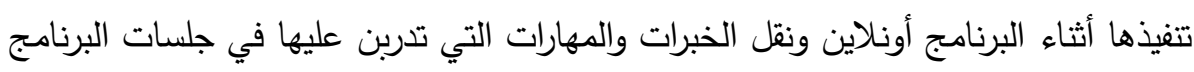

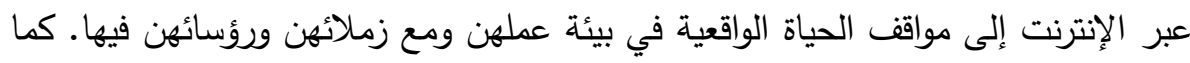

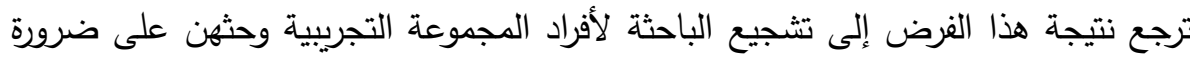
مراجعة الخطة التي وضعوها بالتعاون مع الباحثة لمواجهة التتمر في بيئة عملهن بإيجابية

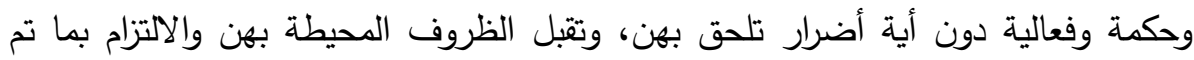

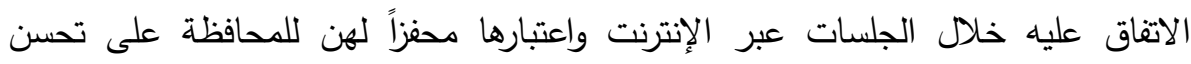

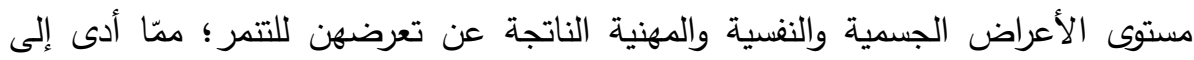
وجود استمرار التحسن في هذه الأعراض، الأمر الذي أدى بدور إلى بقاء النتائج الإيجابية التيات

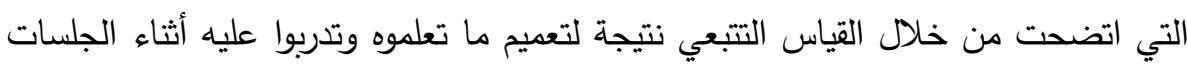

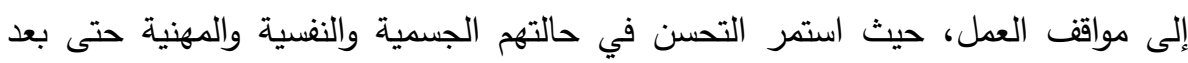
انتهاء تطبيق البرنامج عبر برنامج Skype.

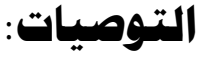

1. الاهتمام بإعداد دورات تدريبية لأعضاء هيئة التدريس بالجامعات حول التتمر وآثاره.

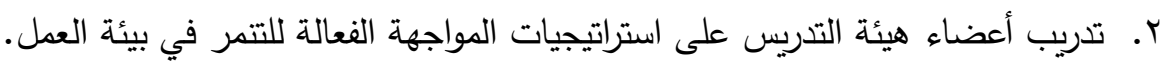

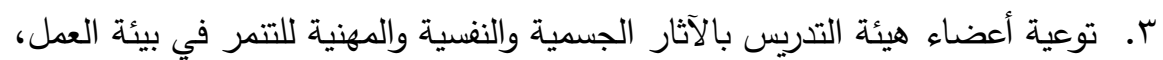

$$
\text { من خلال إعداد البرامج الإرشادية الوقائية. }
$$

ع. توعية الإدارة العليا بالجامعات من خلال تخطيط البرامج الإرشادية الوقائية البائة عن ماهية

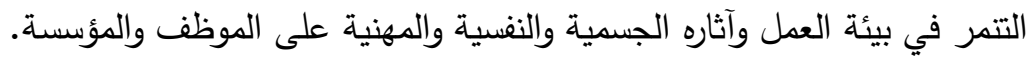

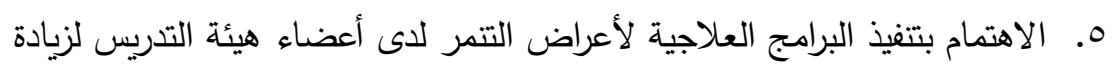
كفاءتهن التدريسية والبحثية.

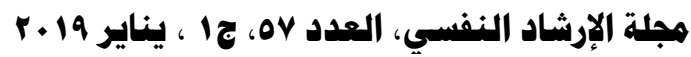




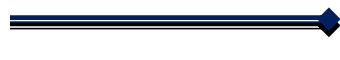

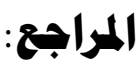

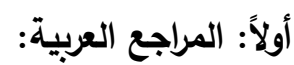

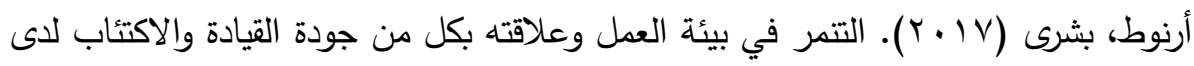

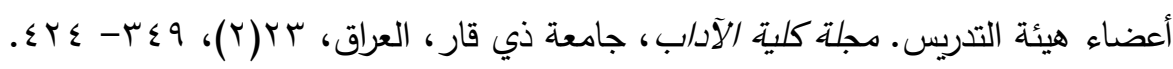

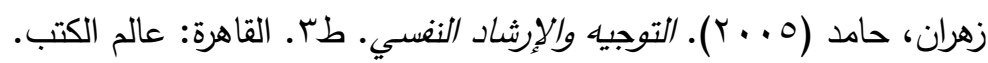

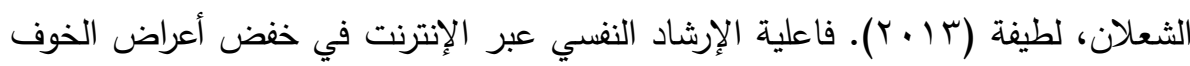

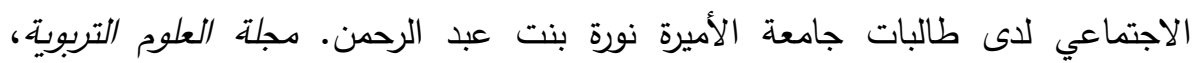

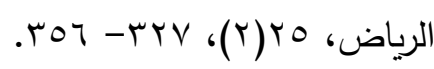

صبحي، سيد (T . . Y). الانسان وصحته النفسية. القاهرة: الدار المصرية اللبنانية.

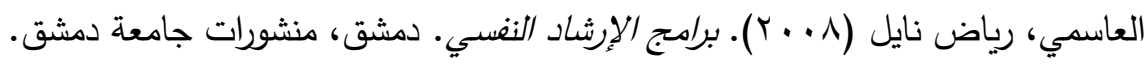

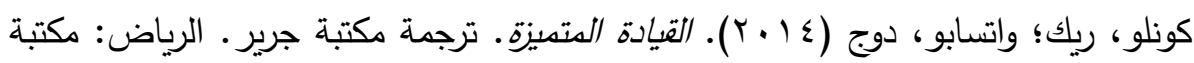

جرير

مخيمر، سيهار صلاح (Y (Y). الإرشاد النفسي عبر الانترنت: ماهيته، أبعاده، وسائل

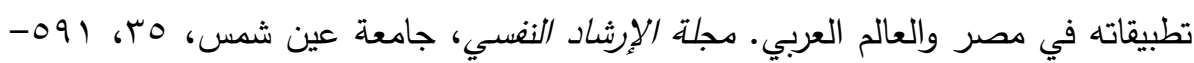

$.7 \cdot V$

ثانياً: المراجع الاجنبية: - أن

Azadeh, S.; Zahrani, H\& Besharat, M.(2016). Effectiveness of Acceptance and Commitment Therapy on Interpersonal Problems and Psychological Flexibility in Female High School Students With Social Anxiety Disorder. Global Journal of Health Science, 8(3),131-138.

Bach,P.,\&Hayes,S.(2002). TheuseofAcceptanceandCommitmentThera pytopr event there hospitalization of psychotic patients: A randomized controlled trial. Journal of Consulting and Clinical Psychology,70, 1129-1139.

Baron, R., \& Neuman, J. (1998). Workplace aggression-The iceberg beneath the tip of workplace violence: Evidence of its forms, frequency, and targets. Public Administration Quarterly,21(4),446464.

Dowling,M\&Rickwood,D.(2013). Online Counseling and Therapy for Mental Health Problems: A Systematic Review of Individual 
Synchronous Interventions Using Chat. Journal of Technology in HumanServices,31(1).

Einarsen, S., \& Mikkelsen, E. (2003). Individual effects of exposure to bullying at work. In S. Einarsen, H. Hoel, D. Zapf \& C. L. Cooper (Eds), Bullying and emotional abuse in the workplace. International perspectives in research and practice. London: Taylor \& Francis.

Hayes,S.,Strosahl,K.,\&Wilson,K.(1999).Acceptanceandcommitmentth erapy:An experiential approach to behavior change. New York: Guilford Press.

Hayes,S;Wilson,K;Gifford,E;Follette,V\&Strosahl,K.(1996).Experienti al avoidance and behavioral disorders: A functional dimensional approach to diagnosis and treatment. Journal of Consulting and Clinical Psychology,64,1152-1168.

Heydari,M;Masafi,S,Jafari;M,Saadat,S\&Shahyad,S.(2018).Effectiven ess of Acceptance and Commitment Therapy on Anxiety and Depression of Razi Psychiatric Center Staff. Open Access Maced J Med Sci; 6(2),410-415.

Hoseinaei,A;Ahadi,H;Fati,L;Heidari,A\&Mazaheri,M.(2013).Impact of acceptance and commitment therapy based group training on job stress and job burnout. Ravanpezeshki va ranashenasi-e-balinie Iran.19(2),109-120.

Karlin B; Walser R; Yesavage J; Zhang A; Trockel M.\& Taylor C.(2013). Effectiveness of acceptance and commitment therapy for depression: comparison among older and younger veterans. Aging Mental Health, 17(5),555-63.

Kazdin,A.(2004).Research design in clinical psychology, $4^{\text {th }}(\mathrm{ed})$.Boston:Allyn\&Bacon.

Kyla A.(2016). Cultural influences and the impact of workplace bullying. Dissertation Presented in Partial Fulfillment Of the Requirements for the Degree Doctor of Philosophy, Capella University.

Lang,A;Schnurr,P;Jain,S;He,F.;Walser,R;Bolton,E;Benedek,D.;Norm an,S;Sylvers,P;Flashman,L;Strauss,J;Raman,R\&Chard,K.(2017).Rand omd controlled trial of acceptance and commitment therapy for distress and impairment in OEF/OIF/OND veterans .Psychology Trauma,9(1),74-84.
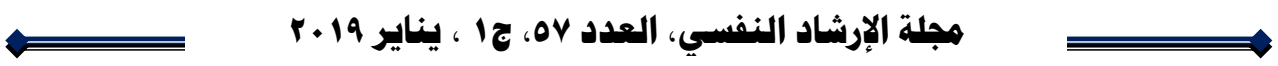


\section{أ.د. بشرى اسماعيل احمد أرنوط}

Marlatt,G.(1994).Addictionandacceptance.InS.C.Hayes,N.S.Jacobson, V.M.Follette, \& M. J. Dougher (Eds.), Acceptance and change: Content and context in psychotherapy (pp.175-197). Reno, NV: Context.

McCracken,L, Vowles K.\& Eccleston C.(2007).Acceptance-based treatment for persons with complex, long-standing chronic pain: A preliminary analysis of treatment outcome in comparison to a waiting phase.xBehavior Research and Therapy. Behav Res Ther,43(10),1335-46.

Narimani,M;Pourabdol,S.\&Bashirpour,S.(2004).Effectiveness of training based on the acceptance / commitment to improving the social well-being of students with specific learning disorder. Quarterly of Pajooheshhaye-Ravenshenasi Ejtemaei,16,107.

Orsillo,S.\&Batten,S.(2005). Acceptance and Commitment Therapy in the Treatment of Posttraumatic Stress Disorder .Behavior Modification,29(1),95-129.

Rajabi,S\&Yazdkhasti,F.(2004).The effectiveness of acceptance and commitment therapy on anxiety and depression among women with MS. Ravanshenasi Balini, 21,29-38.

Roemer,L.,\&Orsillo,S.(2002).Expandingourconceptualizationofandtre atmentforgeneralizedanxietydisorder:Integratingmindfulness/acceptan cebasedapproacheswithexisting cognitive-behavioral models .Clinical Psychology: Science and Practice,9, 54-68.

Salin, D. \& Hoel, H. (2011). Organizational causes of workplace bullying. In Einarsen, S., Hoel, H., Zapf, D., \& Cooper, C. (Eds). Workplace bullying: Development in theory, Research and Practice. London. Taylor \& Francis, 227-243.

Sheehan, M. (1999). Workplace bullying: Responding with some emotional intelligence, International Journal of Manpower, 20, 1-2. Sindahl,T.(2011).Chat counseling for children and youth. Ahandbook. Trine Natasja Sindahl \& Børns Vilkårs Forlag Child Helpline International.

Towsyfyan,N.\&Sabet,F.(2017). The Effectiveness of Acceptance and Commitment Therapy on the Improving of Resilience and Optimism in Adolescents with Major Depressive Disorder. International Journal of Humanities and Social Science, 7(3),239-245.
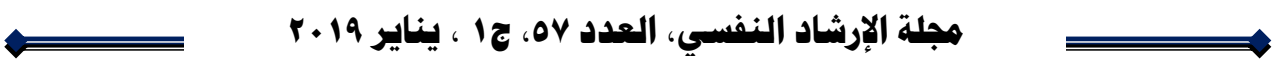


\section{فعالية برناهج قائم على العلاج بالقبول والإلتزام عبر الانترنت}

Vanderbilt, D., \& Augustyn, M. (2010). The effects of bullying. Pediatrics and child health, 20(7), 315-320.

Vartia, M. (2001). Understanding and addressing bullying in the workplace. Industrial and Commercial Training, 40(5), 270-273.

Visinskaite,V.(2015).Workplace bullying: in relation to selfesteem,stress, life satisfaction and Cyberbullying .submitted in partial fulfillment of the requirements of the BAHons in psychology, Dublin Business School, School of Arts, Dublin.

Wilson,K\&Murrell,A.(2003).Values-centered Interventions: setting a course for behavioral treatment. In S. C. Hayes, V. M.. Follette, \& M. Linehan (Eds.) (in preparation). The new behavior therapies: Expanding the cognitive behavioral tradition. New York: Guilford Press.

World Health Organization(WHO).(2010). World health statistics. WHO Library Cataloguing-in-Publication Data: Switzerland.
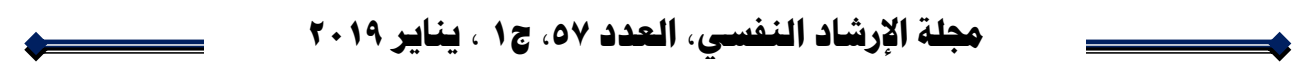


\title{
أ.د. بشرى اسماعيل احمد أرنوط
}

\section{The effectiveness of a program based on accepted and commitment online Therapy to reduce the symptoms of Career bullying in a sample of faculty members}

\author{
Prof. Boshra Ismail Ahmed Arnout \\ Professor of Counseling Psychology \\ Faculty of Education, King Khalid University \\ Faculty of Arts, Zagazig University
}

\begin{abstract}
:
The purpose of the current research was to design a program based on accepted and commitment online Therapy to reduce the symptoms of career bullying, and to verify the effectiveness of this program in reducing the symptoms of bullying, and also to identify the continuity of the impact of this program through the results of sequential measurement after a month and a half to apply. The research sample consisted of (16) female faculty members, their ages ranged between (43-55 years),with an average of age (40.87) year and a standard deviation of (4.926) randomly assigned in two groups experimental and control, each group consisting of (8) persons. Researcher applied Demographic data form and the Symptoms of career bullying and Program Based on accepted and commitment online Therapy, all these tools are prepared by the researcher. The results of the study showed that there were statistically significant differences at (0.01) between the average control and experimental groups in the post-career bullying symptoms scale in favor of the experimental group members. There were statistically significant differences at the level of (0.01) between the experimental group averages in the pre and post- career bullying symptoms scale in favor of the postapplication, in addition to there were no statistically significant differences between the mean scores of the experimental group in the post and follow-up in the scale of symptoms of career bullying. The results of the research were explained in light of the theoretical framework and previous studies. The researcher also made a number of recommendations and research proposals.

Keywords: Program, Acceptance and Commitment Therapy, Online Therapy, Career Bullying.
\end{abstract}
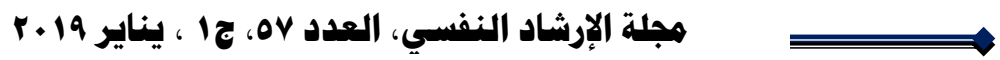